\title{
O direito fundamental à alimentação e sua proteção jurídico- internacional
}

\author{
The fundamental right to food and its legal and international protection
}

Osvaldo Ferreira de Carvalho ${ }^{1}$

\section{Resumo}

Este artigo versa sobre o direito fundamental à alimentação e sua proteção jurídico-internacional. Tal direito encontra-se reconhecido em diversos instrumentos internacionais como na Declaração Universal de Direitos Humanos e no Pacto Internacional de Direitos Econômicos, Sociais e Culturais (PIDESC). O direito fundamental à alimentação é indivisivelmente vinculado à dignidade da pessoa humana, sendo indissociável da justiça social ao requerer dos atores estatais a adoção de políticas públicas orientadas para a erradicação da fome e da pobreza. A pesquisa se deteve a examinar os instrumentos de Direito Internacional e as constituições estatais que preveem o direito à alimentação ao estabelecer os contornos necessários para uma dogmática emancipatória.

Palavras-chave: Direitos fundamentais. Direitos sociais. Direito à alimentação. Proteção internacional.

\section{Abstract}

This article deals with the fundamental right to food and its legal and international protection. This right is recognized in various international instruments as the Universal Declaration of Human Rights and the International Covenant on Economic, Social and Cultural Rights (ICESCR). Devout, initially, to examine the idea of the state of fundamental rights to be a political model is founded on the guarantee of enforcement of fundamental rights. It is analyzed that the right to food is a fundamental right of self because their fundamental formal and material. Moreover, represents a social right of immediate benefit in the form of legally enforceable and binding precept. This right is indivisibly linked to human dignity, is inseparable from social justice to require state actors the adoption of public policies to eradicate hunger and poverty. The research was held to examine the instruments of international law and the constitutions that predict the right to food in establishing the contours needed for a dogmatic emancipation.

Keywords: Fundamental Rights. Social rights. Right to food. International protection. Efficacy.

1 Doutorando em Direito pela Universidade de Lisboa, Mestre em Direito, Professor universitário nos cursos de Graduação e Pós-Graduação. Pesquisador da Fundação de Amparo à Pesquisa no Estado de Goiás (FAPEG). 


\section{Introdução}

O tema que ora se pretende investigar parte do pressuposto de que há o direito fundamental à alimentação socialmente construído como consequência das lutas promovidas pelos movimentos sociais, como é o caso do combate à fome evidenciado por um processo dinâmico pela luta de grupos excluídos ao conduzirem à esfera pública seus sofrimentos ao exigirem, portanto, reparação.

O direito fundamental ou humano ${ }^{2}$ a uma alimentação adequada está reconhecido em diversos instrumentos internacionais ao encontrar-se previsto originalmente no art. 25 da Declaração Universal dos Direitos Humanos, onde é examinado no contexto da promoção do direito a um padrão adequado de vida. Este direito é reafirmado no art. 11 do Pacto Internacional de Direitos Econômicos, Sociais e Culturais (PIDESC).

O direito fundamental à alimentação constitui um direito de segunda dimensão, denominado de direito social. ${ }^{3}$ A nota distintiva deste direito é a sua dimensão positiva, uma vez que se cuida não mais de evitar a intervenção do Estado na esfera da liberdade individual, mas, sim, de propiciar um direito de participar do bem-estar social. O que caracteriza este direito é a sua dimensão positiva, dado que objetiva não mais obstar as ingerências do Estado no âmbito das liberdades individuais, mas exigir do Estado a sua intervenção para atender as crescentes necessidades do indivíduo. São direitos de crédito porque, por meio deles, o ser humano, passa a ser credor das prestações sociais estatais (LAFER, 1988, p. 127).

Impende consignar que os direitos fundamentais (humanos) sociais são, tanto no plano universal quanto no regional, objeto de numerosos pactos, tratados, declarações,

\footnotetext{
Segundo percuciente lição do expoente professor da Universidade de Lisboa, José Melo Alexandrino (2011, p. 36-37), os direitos humanos não se diferenciam dos direitos fundamentais. Aqueles, os direitos humanos, são direitos da pessoa humana reconhecidos pelas normas de Direito Internacional em vigor (por normas de costume, de tratados ou por princípios de Direito Internacional); ao passo que os direitos fundamentais são direitos previstos na Constituição (podendo estes conceber-se como processo jurídico de institucionalização daqueles), estando necessariamente configurados e limitados pela Constituição (sistema de direitos fundamentais).

3 Conforme profícua lição de Ingo Wolfgang Sarlet (2009, p. 220), o qualificativo social não está exclusivamente vinculado a uma atuação positiva do Estado na promoção e na garantia de proteção e segurança social, como instrumento de compensação de desigualdades fáticas manifestas e modo de assegurar um patamar pelo menos mínimo para uma vida digna, porém, também, são direitos sociais que asseguram e protegem um espaço de liberdade ou mesmo dizem com a proteção de determinados segmentos da sociedade, em razão da sua maior vulnerabilidade perante o poder estatal, mas acima de tudo social e econômico.
} 
convenções e resoluções, cristalizaram-se ao longo do tempo como componentes elementares da order public internacional. ${ }^{4}$

O reconhecimento dos direitos fundamentais sociais se manifesta não apenas em documentos internacionais, mas também em numerosas constituições. Assim, podem-se mencionar, exemplificativamente, no círculo jurídico ibero-americano, os pormenorizados catálogos de direitos fundamentais sociais nas constituições do Brasil, de Portugal e da Espanha.

As garantias dos direitos fundamentais sociais não se esgotam no plano interno do Estado, senão que transcendem ao plano internacional ou supranacional mediante distintas instituições e mecanismos. Para isso existem o Pacto Internacional de Direitos Econômicos, Sociais e Culturais das Nações Unidas (PIDESC), acima referido, e seu órgão de monitoramento, o Comitê de Direitos Econômicos, Sociais e Culturais das Nações Unidas (CDESC). Este Comitê afirmou que o direito a uma alimentação adequada está inseparavelmente vinculado à dignidade da pessoa humana e é indispensável para o desfrute de outros direitos humanos consagrados na Carta Internacional de Direitos Humanos. Além disso, é indissociável da justiça social, visto que requer a adoção de políticas econômicas, ambientais e sociais adequadas nos planos nacional e internacional, orientadas para a erradicação da pobreza tendo em vista o alcance de todos os direitos humanos por todos. $^{5}$

Cumpre aqui sustentar que uma ética de direitos fundamentais decorre diretamente da dignidade da pessoa humana. De fato, este valor e princípio fundamental do Estado Social e Democrático de Direito equivale a um lugar-comum para o abrigo de todas as gerações ou dimensões dos direitos fundamentais. A justiça social não pode ser pensada isoladamente sem reportar-se à dignidade da pessoa humana. A própria Declaração Universal dos Direitos Humanos de 1948 lhe confere tal posição de superioridade ante os demais princípios e valores.

4 Flávia Piovesan $(2008$, p. 6) aduz que o processo de universalização dos direitos humanos permitiu a formação de um sistema internacional de proteção desses direitos. Esse sistema, conforme leciona a referida autora, é integrado por tratados internacionais de proteção que refletem, sobretudo, a consciência ética contemporânea compartilhada pelos Estados ao invocarem o consenso internacional acerca de temas centrais dos direitos humanos, na busca da salvaguarda de parâmetros protetivos mínimos.

5 General Comment no 12 - E/C.12/1999/5, 12 may 1999. Disponível em: <http://www2.ohchr.org/english/bodies/cescr/comments.htm>. Acesso em: 08 dez. 2011. 
A formulação de um direito fundamental à alimentação deve hoje ser vista e desenvolvida de forma inseparável com o direito humano à nutrição, ${ }^{6}$ visto que o alimento só adquire uma verdadeira dimensão humana quando o ser humano se encontra bem nutrido, saudável, digno e cidadão (VALENTE, 2003, p. 54).

Ademais, o tema enseja, indiscutivelmente, forte aproximação com outros direitos fundamentais, como o direito à vida e à saúde ao lançar a premissa de que o direito à alimentação se converte (ou traduz) em vida e saúde. Então, buscar-se-á verificar se o direito fundamental à alimentação constitui uma posição jurídica autônoma em relação ao direito à vida e à saúde ou é tipicamente decorrente destes. Sustentamos pela posição jurídica autônoma ante sua consagração institucional nos principais documentos internacionais e nacionais, como o fez a Constituição brasileira com o advento da EC no 64/2010 ao acrescer mais este direito fundamental em seu catálogo.

Optou-se por escolher o direito fundamental à alimentação dentre os diversos direitos sociais por alguns motivos: primeiro, em razão de que urge garanti-lo, concretizá-lo com a máxima urgência, precipuamente no Brasil. Além disso, por causa dos programas de combate à fome e daqueles dedicados a segurança alimentar da população ao constituírem temas prioritários na agenda, nomeadamente, do Estado brasileiro sob amplo debate, público e governamental, acerca dos objetivos e critérios imprescindíveis para o planejamento e construção das políticas públicas para implementá-lo. Regidos pelo ciclo político-eleitoral, os debates variam de intensidade nas diferentes instâncias de governo, tendo em vista as demandas provindas das organizações sociais nacionais e também as pressões de ordem internacional.

\section{Estado de Direitos Fundamentais}

A atual identificação do moderno Estado de Direito ${ }^{7}$ - fundado na separação dos poderes, superioridade da lei, na garantia dos direitos individuais e na supremacia da

PIDESC, art. 11, §2으, alíneas $a$ e $b$.

7 De acordo com a proficiente lição de Jorge Reis Novais (2004, p. 20-21), o Estado de Direito pode genericamente definir-se como sendo um Estado limitado e organizado juridicamente com vistas na garantia dos direitos fundamentais dos cidadãos. Além disso, na esteira do pensamento do citado autor, independentemente das diferentes modalidades de concretização política, o ideal de Estado de Direito propõe-se sempre a garantia da segurança, liberdade e propriedade por meio de: (1) uma marcada separação entre o Estado e a sociedade que permita a esta constituir-se em espaço autorregulado onde 
Constituição ao dar impulso decisivo ao reconhecimento e positivação dos direitos fundamentais - constitui-se um Estado de direitos fundamentais ${ }^{8}$ como modelo político apostado na garantia de efetivação dos direitos fundamentais do homem, ressaltando-se que se trata, consoante magistério de Paulo Otero (2009, p. 525), de um Estado baseado no homem e ao serviço do homem.

O Estado de direitos fundamentais alicerça-se no respeito pela dignidade, encontrando-se ao serviço da garantia da inviolabilidade dessa mesma dignidade que é inerente a cada pessoa individual e concreta (OTERO, 2009, p. 525).

Cumpre anotar que as Constituições brasileira e portuguesa foram inequívocas na consagração da dignidade da pessoa humana conforme se lê no artigo $1 \stackrel{0}{ }$, inciso III, da Constituição da República Federativa do Brasil de 1988 (CRFB/1988) e artigo 1o da Constituição da República Portuguesa de 1976 (CRP/1976), para ficar apenas com essas previsões textuais. Jorge Reis Novais (2004, p. 56-59) adverte que a dignidade da pessoa humana não deve ser entendida segundo um padrão oficial, trata-se de compreendê-la de forma pluralista, aberta e tolerante, pois cada um define seus planos e forma de vida inseridos em sua própria compreensão de dignidade.

A ideia de Estado de direitos fundamentais permite perceber a centralidade assumida pelos direitos fundamentais - e mais propriamente pela dignidade da pessoa humana - nos textos constitucionais e na estruturação e atuação estatais; não mais se concebe a Constituição como instrumento normativo voltado primordialmente à organização do poder, mas como instrumento organizador de um poder que se volta ao reconhecimento e garantia dos direitos fundamentais (QUEIROZ, 2006, p. 88).

Os direitos fundamentais convocam, desde logo, o Estado e as demais entidades públicas à sua garantia e efetivação: todas as entidades públicas se encontram especialmente vinculadas às normas sobre direitos fundamentais como principais sujeitos

coexistam e concorram as esferas de autonomia econômicas e morais dos cidadãos; (2) uma redução da atividade do Estado ao mínimo exigido para a garantia da paz social e das condições objetivas que viabilizem o encontro das autonomias individuais e o livre desenvolvimento da personalidade de cada um; (3) uma transformação progressiva de toda a atividade do Estado em atuação fundada, organizada e limitada juridicamente e uma concepção jurídica, regulada pelo Direito, das relações que o Estado mantém com os cidadãos.

8 Essa expressão também é utilizada por Cristina Queiroz (2006, p. 88). Esta expoente jurista lusitana ensina, com acuidade, que o moderno Estado de Direito democrático e constitucional constitui um Estado de direitos fundamentais. 
passivos das respectivas vinculações constitucionais, traduzindo-se o seu respeito e a sua implementação numa tarefa fundamental do Estado ou, em termos mais genéricos, uma incumbência jurídica pública (OTERO, 2009, p. 535).

Em magistral lição de José Melo Alexandrino (2011, p. 23), um direito fundamental pode, pois, definir-se como uma situação jurídica das pessoas perante os poderes públicos consagrada na Constituição.

Ainda, de acordo com o jurista supracitado, os direitos fundamentais são necessariamente posições jurídicas: fundamentais, porque define relações qualificadas do homem e do Estado, uma vez que esses direitos desenham respostas a necessidades fundamentais e constantes do ser humano quanto às esferas de existência, da autonomia e do poder; universais, pois se apresentam atribuídos a categorias particulares de pessoas, constituem direitos de todas as pessoas; permanentes, visto que se apresentam como direitos que não podem ser e deixar de ser, apenas se extinguindo pela morte do respectivo titular ou por uma decisão de valor constituinte que suprima o direito ${ }^{9}$; pessoais, por estarem estritamente ligados à pessoa, à sua vida e personalidade, sendo dela inseparáveis; não patrimoniais, porquanto são direitos insuscetíveis de avaliação pecuniária, razão pela qual são ainda intransmissíveis e inexpropriáveis; e, indisponíveis, já que o caráter inalienável do direito vincula não só o Estado como o próprio titular, que não poderia, por exemplo, celebrar um contrato de escravidão (ALEXANDRINO, 2011, p. 24).

\subsection{Estado Constitucional e direitos fundamentais}

O Estado Constitucional, esculpido pelos princípios da juridicidade, da democracia e da socialidade, ${ }^{10}$ pode ser designado Estado de Direitos Fundamentais ao considerar a

9 Aspecto que ousamos divergir do expoente jurista, uma vez que os direitos fundamentais venham a existir no mundo do Direito já se incorporam ao patrimônio jurídico da humanidade, não sendo possível serem eliminados nem mesmo pelo Poder Constituinte Originário ao estar este sujeito aos limites transcendentes, isto é, os que provém de imperativos de Direito natural, de valores éticos superiores e de uma consciência jurídica comunitária, como os que prendem aos direitos fundamentais conexos com a dignidade da pessoa humana. Nesse sentido: MIRANDA, 2008, p. 15.

O princípio da juridicidade ou do Estado de Direito impõe que as atuações estatais se pautem por critérios jurídicos preestabelecidos, densifica juridicamente o propósito político de submeter o poder à disciplina e aos limites jurídicos e pode ser reconduzido a subprincípios como o sistema de direitos fundamentais, a divisão de poderes, a legalidade da Administração, a vedação do excesso, a segurança jurídica e a proteção da confiança. CANOTILHO, 2003. p. 243-245. Segundo magistral lição de Canotilho, na página 245 da obra mencionada, o princípio de juridicidade aponta, também, para a ideia de justiça, para um Estado de justiça em que se observam e protegem os direitos, incluindo os direitos das minorias, bem como se destaca pela 
centralidade assumida pelos direitos fundamentais como fim e medida da estruturação, organização e atuação do Estado e do seu relacionamento com a sociedade e com os indivíduos, ${ }^{11}$ conforme alinhavado no tópico anterior. Esta centralidade liga-se à dignidade da pessoa humana, que habita o vértice do sistema de direitos fundamentais inerente e estrutural ao Estado Constitucional, informando-o e justificando-o. Conforme já afirmado anteriormente, a dignidade da pessoa humana, numa concepção plural, aberta e tolerante (NOVAIS, 2004, p. 56-59), é o valor fundante da ordem jurídica, perpassa-a em toda a sua extensão, permeando-a com os direitos fundamentais a ponto de se poder justificar a denominação "Estado de Direitos Fundamentais" ou "Estado fundado na dignidade da pessoa humana" (NOVAIS, 2006, p. 12).

Afastando a concepção segundo a qual os direitos fundamentais seriam criações do Direito positivo e, assim, concessões do Estado, entende-se aqui que há imposições originadas da dignidade da pessoa humana que antecedem o Estado, condicionam e limitam, ao mesmo tempo que fundamentam, seu poder e o próprio Direito positivo; ${ }^{12}$ com esta premissa, reconhece-se a centralidade dos direitos fundamentais para o Estado Constitucional e sua ordem jurídica. Os direitos fundamentais, neste enquadramento, expressam escolhas básicas da comunidade política que, plasmadas na Constituição conferem-Ihes substrato material-valorativo, impregnando-a das derivações da dignidade

equidade na distribuição de direitos e deveres fundamentais e na determinação da divisão de benefícios da cooperação em sociedade, em que existe, ainda, igualdade de distribuição de bens e igualdade de oportunidade.

Quanto ao princípio democrático, também tradução jurídica de um propósito político, ou seja, garantir a titularidade do poder pelo povo apresenta dimensões materiais e dimensões organizativo-procedimentais. Sugere a existência de um objetivo a realizar por meio da democracia. CANOTILHO, 2003, p. 287-288.

De acordo com Canotilho, o princípio da socialidade impõe a vinculação jurídica do Estado a atuar na criação de condições de existência digna para as pessoas, até mesmo como garante de sua liberdade e autonomia. O princípio, especificamente no campo social, pode ser reconduzido a uma dimensão subjetiva concretizada por meio dos direitos sociais e a uma dimensão objetiva que obriga o Estado à "transformação das estruturas econômicas" voltada à igualdade social, ou seja, o Estado deve também ser conformador na busca de "dignidade social". CANOTILHO, 2003, p. 337-338, 341-343, 348-349.

11 Jorge Reis Novais (2006, p. 12) propôs deslocar a tônica, na configuração do Estado de Direito, do império da lei para os direitos fundamentais. Cristina Queiroz $(2006$, p. 88) leciona que no moderno Estado de Direito Democrático e Constitucional por ser um Estado de Direitos Fundamentais, o status positivus deve voltar a ser posicionado no mesmo plano do status negativus. Paulo Bonavides (2004, p. 600) sintetiza a ideia ao afirmar que os "direitos fundamentais são a bússola da Constituição".

12 É possível travar discussões acerca desta relação se seria uma questão de validade do Direito positivo, uma questão de legitimidade ou de justiça. Consigna-se o questionamento ao anotar que se adere à ideia de que a dignidade e, assim, os direitos fundamentais, se impõem ao Estado e à sua ordem jurídica. Os direitos fundamentais são direitos do homem que se impõem ao Estado, mas são direitos que somente se realizam por meio do Estado. Mencione-se quanto a isso as seguintes lições: ANDRADE, 2004. p. 111; LUÑO, 2005. p. 116-119, 576; NOVAIS, 2006, p. 25-26. 
da pessoa humana, ${ }^{13}$ com capacidade irradiante para toda a ordem jurídica e vinculante de qualquer atuação estatal (SARLET, 2007, p. 173-174, 407)

A fundamentalidade das normas jusfundamentais é compreendida por meio das dimensões subjetiva e objetiva que se complementam e permitem captar todas as suas virtualidades. $^{14} \mathrm{~A}$ dimensão subjetiva coloca em destaque a qualidade dos direitos fundamentais como direitos subjetivos do indivíduo dirigidos contra o Estado (SARLET, 2007, p. 178-180). A dimensão objetiva denota a ordem valorativa objetiva representada pelos direitos fundamentais e que se espraia como dimensão básica jurídico-constitucional por todo o sistema normativo (ANDRADE, 2004, p. 115-116). Os direitos fundamentais são uma das decisões políticas básicas da Constituição que plasma valores éticos e políticos que vão determinar as relações entre indivíduos e o Estado, bem como a organização e atuação estatais, funcionando como diretriz interpretativa basilar para todo o ordenamento jurídico. Por meio da dimensão objetiva explica-se a força irradiante dos direitos fundamentais. Logo, a partir do topo da ordem constitucional estes critérios objetivos destes valores conferemIhe unidade e coerência.

José Carlos Vieira de Andrade (2004, p. 60-62; 115-117) realça que a dimensão objetiva dos direitos fundamentais se liga à ultrapassagem do modelo liberal de Estado e à afirmação de uma concepção do homem não como ser isolado, mas como membro de uma comunidade, com liberdades limitáveis em prol dessa sua inserção na sociedade e com necessidades a serem atendidas pelo Estado. $\mathrm{O}$ autor destaca que no âmbito de cada direito fundamental é traçado um espaço normativo que se preenche por valores que se afirmam como bases da ordenação da vida social, possibilitando a produção de efeitos jurídicos que complementam a dimensão subjetiva.

Daniel Sarmento $(2008$, p. 108) leciona que o reconhecimento da dimensão objetiva dos direitos fundamentais não significa depreciar a sua dimensão subjetiva, mas reforço a ela. Segundo ele, a dimensão objetiva complementa a subjetiva ao agregar a esta uma "mais valia", conferindo proteção robustecida aos direitos fundamentais mediante esquemas que transcendem a estrutura relacional típica dos direitos subjetivos.

13 Jorge Miranda (2000, p. 180) ensina que a dignidade da pessoa humana situa a pessoa como fundamento e fim da sociedade e do Estado.

14 As dimensões subjetiva e objetiva podem ser mais bem compreendidas e elucidadas na obra do expoente jurista lusitano José Carlos Vieira de Andrade (2004, p. 133 e seguintes). 
Para além das dimensões objetiva e subjetiva, a fundamentalidade dos direitos fundamentais permite cogitar de sua multifuncionalidade, das múltiplas funções que desempenham, dentre as quais se destacam: (a) de defesa ou liberdade, (b) de prestação social, (c) de proteção perante terceiros e (d) de não discriminação. ${ }^{15}$

\subsection{A decisiva dimensão social do atual Estado de Direito}

O antecedente histórico do constitucionalismo instituidor do Estado Social se apresenta pela preocupação com a condição social do homem, sobretudo pelas pressões das classes trabalhadoras e dos movimentos teóricos e políticos de contestação do funcionamento econômico capitalista com o fim de conter o arbítrio do poder econômico, governado pelo lucro e pela acumulação de capital.

As primeiras referências aos direitos sociais projetam-se na Inglaterra ante o impacto que a questão social ${ }^{16}$ ensejou, ocorrendo mais cedo do que na Europa continental em razão do prematuro desenvolvimento inglês ao justificar a edição da Poor Law.

As Poor Law inglesas identificadas no século XVII, especificamente no ano de 1601, tiveram o importante papel de oficializar ou consolidar a formalização da substituição da contribuição voluntária pela obrigatória com o fim de destinar recursos para a assistência pública aos necessitados em que o dever moral ou religioso é substituído pela obrigação legal (BITENCOURT NETO, 2010, p. 44). Este sistema foi alterado em 1834 com o Poor Law Amendment Act, cingindo-se a assegurar as condições existenciais daqueles que apresentassem alguma incapacidade para a atividade laboral, como idade avançada ou doença (DANTAS, 2009, p. 192).

Pode-se dizer que o Estado Social de Direito surgiu como resposta às crescentes necessidades que a sociedade não podia suprir por si só e como resposta a outro modelo de

15 Sobre cada uma das funções, veja-se em: Canotilho (2003, p. 407-410).

16 De acordo com o magistério de Miguel Calmon Dantas (2009, P. 179), a questão social não se caracteriza por um conjunto de problemas sociais que são coetâneos e próprios de determinadas épocas, mas se revela como uma decorrência estrutural do sistema econômico capitalista, fundado na economia de livre mercado, dirigida pelo poder econômico, governado pelo lucro e pela acumulação de capital. Trata-se de um problema acerca das próprias estruturas das relações sociais, derivadas da adoção do sistema econômico capitalista ao exprimir uma autorrepresentação da coletividade como sociedade, em que os vínculos sociais são frouxos e efêmeros, conduzidos os indivíduos pelos intentos egoísticos próprios do individualismo. Constitui uma designação dos efeitos do funcionamento econômico sobre a maneira pela qual os indivíduos se encontram perturbados ou ameaçados quanto ao modo de inserção no trabalho e à capacidade de produzir e obter as condições materiais de que necessitam. 
Estado erigido com a pretensão de suprir tais necessidades: o Estado socialista soviético. A consagração do Estado Social de Direito teve forte influência da Doutrina Social da Igreja, ${ }^{17}$ já que significou solução reformista para os problemas sociais, sem ruptura com o sistema capitalista, podendo-se dizer que, tendo sido impulsionado pela "ameaça socialista", adotou solução social que preservou a liberdade individual e a propriedade privada. Por outro lado, o elemento democrático buscou afastar da memória europeia as experiências autoritárias que vigeram, em boa parte dos países, até o fim da Segunda Guerra Mundial.

Conforme leciona Paulo Otero (2009, p. 335), a influência do magistério da Doutrina Social da Igreja constitui forte contributo para a instituição de um Estado Social, pois desde os finais do século $\mathrm{XIX}^{18}$ denunciava a incapacidade do liberalismo em resolver a questão social ao combater o individualismo selvagem e implementar a justiça social por meio de um modelo de bem-estar, determinando que as autoridades públicas promovam o auxílio à família, o desenvolvimento da função social da propriedade privada, a defesa dos trabalhadores e da sua dignidade contra os abusos decorrentes de uma exploração econômica desenfreada à luz da livre concorrência.

Este percurso acima delineado, em que os primeiros direitos sociais começam a ser reconhecidos, sem importar numa sistemática direção do Estado por ações e políticas públicas sobre a ordem econômica, pode ser concebido como representativo das bases do Estado Social que se inaugura, efetivamente, no primeiro quartel do século XX.

Quanto à consagração constitucional deste novo modelo estatal que, ao lado dos direitos de liberdade, assumem posição de relevo os chamados direitos sociais; mencionamse correntemente a Constituição mexicana de 1917 e a Constituição de Weimar de 1919. Esses instrumentos normativos deram destaque aos direitos sociais, demonstrando que a segunda geração de direitos vinha se somar a primeira - de caráter liberal - na busca de garantias substanciais e não meramente formais (LUÑO, 2004, p. 213).

Antonio Enrique Pérez Luño (2004, p. 214) pontifica, à luz da experiência do direito espanhol, que a implantação das liberdades concretas - satisfação das necessidades básicas

17 Registra-se o escólio de Jorge Reis Novais (2004, p. 56) para quem a dignidade da pessoa humana, um dos fundamentos do Estado Social de Direito, teve inegável influência do cristianismo em sua origem.

18 Foi por meio da Carta Encíclica Rerum Novarum, de 15 de maio de 1891, o Papa Leão XIII (1878-1903), insurgindo-se contra a situação de exploração dos operários e a pobreza gerada pelo liberalismo e, por outro lado, contra as ideias socialistas contrárias à propriedade privada, procede, segundo os princípios da justiça e da verdade, à edificação da doutrina social da Igreja ao evitar que a direção do movimento social ficasse restrito dos partidos revolucionários. OTERO, 2009, p. 292. 
e fomento das capacidades e potencialidades humanas -, ao concretizar o livre desenvolvimento da personalidade, requer-se a ação positiva dos poderes públicos com objetivo de remover os obstáculos de ordem econômica, social e cultural que impedem a plena expansão da pessoa humana. Para o ínclito jurista citado, a estas exigências tencionou responder o Estado Social de Direito ou, acentuando sua orientação libertadora e emancipadora, o Estado Social e Democrático de Direito, postulado da Constituição espanhola. Logo, para o autor, neste modelo de organização política não cabe uma ruptura entre liberdades individuais e direitos sociais, pois em seu âmago os direitos sociais são direitos de liberdade (LUÑO, 2004, p. 214-215).

Uma das características centrais do Estado Social de Direito é a existência de direitos fundamentais sociais a prestações, incluindo prestações normativas e prestações fáticas (ALEXY, 2007, p. 427-428). Mesmo na Lei Fundamental de Bonn, que opta pela consagração da cláusula genérica de Estado Social, a doutrina e a jurisprudência identificam direitos a prestações materiais implícitos ou adscritos. A Constituição portuguesa de 1976, tendo nascido no contexto de processo revolucionário que partiu de uma "decisão socialista", ${ }^{19}$ caracteriza-se pelo extenso rol de direitos sociais a prestações, embora tenha estruturado o sistema de direitos fundamentais com relevância inegável dos direitos de liberdade individual.

Projeta-se um modelo, com o Estado Social de Direito, onde o bem-estar e o desenvolvimento social pautam as ações do ente público (STRECK, 2010, p. 96). O Estado Social se diferencia dos aparatos de assistência pública próprios do modelo liberal, especialmente, pela cominação ao Estado do dever de buscar a justiça social por ampla e direta intervenção na sociedade, a qual já não se satisfaz com ações assistencialistas, antes pressupõe direitos fundamentais sociais. O novo princípio que informa o Estado - o da socialidade $^{20}$ - impõe ações que garantam as condições para uma existência digna dos

19 Sobre a decisão socialista no texto originário da Constituição portuguesa de 1976, cf. CANOTILHO, 2003. p. 335-336; MIRANDA, 2003, p. 363-365, 382-409.

20 A consagração do princípio da socialidade ou princípio social como estruturante do Estado é contemporânea ao advento do Estado Social em uma conjuntura histórica na qual a legitimidade e operatividade do Estado de Direito exigiram repensar as fronteiras de atuação pública em virtude dos resultados socioeconômicos da abstenção estatal e da atuação livre do mercado; a intervenção do Estado nas esferas social e econômica mostrou-se imprescindível. Este princípio traduz, desta forma, a vinculação jurídica do Estado a atuar na criação de condições de existência digna para as pessoas, até mesmo como garante de sua liberdade e autonomia. CANOTILHO, 2003, p. 337-338, 341-343, 348-349. O princípio, especificamente no campo social, pode ser reconduzido, conforme lição de Canotilho (2003, p. 348-349), a 
cidadãos, bem como para a "prossecução de uma justiça social generalizada" (NOVAIS, 2006,

p. 184), mediante a prestação de bens, serviços e infraestruturas, e não apenas com aparatos de segurança social.

\section{Direitos sociais: sentido, universalidade, indivisibilidade e interdependência}

Os direitos fundamentais (ou humanos - estes por alçarem posição no plano de Direito Internacional Público) sociais são, tanto no plano universal quanto no regional, objeto de numerosos pactos, tratados, declarações, convenções e resoluções, cristalizaramse ao longo do tempo como componentes elementares da order public internacional. ${ }^{21}$

Fortalece-se a ideia de que a proteção dos direitos fundamentais sociais não se deve reduzir ao domínio reservado do Estado, pois revela tema de legítimo interesse internacional. Em perspectiva global, são exemplificativamente mencionáveis a Declaração Universal dos Direitos Humanos, de 10 de dezembro de 1948, a qual contém nos artigos XXII e seguintes, um amplo catálogo de direitos sociais. Em 16 de dezembro de 1966, a Assembleia Geral das Nações Unidas adotou o Pacto Internacional sobre Direitos Econômicos, Sociais e Culturais que desenvolveu pormenorizadamente o conteúdo dos direitos fundamentais (ou humanos) sociais da Declaração Universal de $1948 .^{22}$

uma dimensão subjetiva concretizada por meio dos direitos sociais e a uma dimensão objetiva que impõe ao Estado a "transformação das estruturas econômicas" voltada à igualdade social, ou seja, o Estado deve também ser conformador na busca de "dignidade social".

21 Flávia Piovesan (2008, p. 6) aduz que o processo de universalização dos direitos fundamentais (ou humanos) permitiu a formação de um sistema internacional de proteção desses direitos. Esse sistema, conforme leciona a referida autora, é integrado por tratados internacionais de proteção que refletem, sobretudo, a consciência ética contemporânea compartilhada pelos Estados ao invocarem o consenso internacional acerca de temas centrais dos direitos humanos, na busca da salvaguarda de parâmetros protetivos mínimos.

22 Impende noticiar que os dois pactos internacionais adotados pela Assembleia Geral das Nações Unidas pela Resolução n. 2.200-A (XXI Sessão), em 16 de dezembro de 1966, a saber, Pacto Internacional sobre Direitos Civis e Políticos (PIDCP) e o Pacto Internacional sobre Direitos Econômicos, Sociais e Culturais (PIDESC), os quais foram ambos os textos aprovados pelo Brasil pelo Decreto Legislativo no 226, de 12 de dezembro de 1991, tendo sido o PIDESC assinado em 24 de janeiro de 1992 e entrou em vigor no Brasil em 24 de abril de 1992, sido promulgado pelo Presidente da República via Decreto no 591, de 6 de julho de 1992. O Estado português ratificou o PIDESC a mais tempo pela Lei no 45/1978, de 11 de julho de 1978. Quanto ao Pacto Internacional sobre Direitos Civis e Políticos (PIDCP), este entrou em vigor no Brasil em 24 de abril de 1992 e promulgado pelo Presidente da República via Decreto no 592, de 6 de julho de 1992. O Estado português assinou o PIDCP em 7 de outubro de 1976 e aprovado para ratificação pela Lei no 29/78, de 12 de Junho de 1978, publicada no Diário da República, I Série A, no 133/78 (retificada mediante aviso de retificação publicado no Diário da República no 153/78, de 6 de Julho de 1978) e entrou em vigor na ordem jurídica portuguesa em 15 de setembro de 1978. 
Ladeado pelos esforços globais por uma proteção dos direitos fundamentais sociais, há, também, no plano regional, numerosas convenções e declarações. Digna de salientar é a Convenção Americana de Direitos Humanos de 1969, também denominada de Pacto de San José da Costa Rica (PIOVESAN, 2009, p. 44). Esta Convenção foi assinada em San José, Costa Rica, em 22 de novembro de $1969 .^{23}$

Segundo Flávia Piovesan (2009, p. 46), a Convenção Americana não enuncia de forma específica qualquer direito social, cultural ou econômico, limitando-se a determinar aos Estados que alcancem, progressivamente, a plena realização desses direitos, mediante a adoção de medidas legislativas e de outras medidas que se mostrem apropriadas, nos termos do art. 26 da Convenção. ${ }^{24}$ Posteriormente, em 1988, a Assembleia Geral da Organização dos Estados Americanos (OEA) adotou um Protocolo Adicional à Convenção referente aos direitos sociais, econômicos e culturais - Protocolo de San Salvador -, que entrou em vigor em 16 de novembro de 1999, no qual numerosos direitos sociais estão normatizados. $^{25}$

Dos sistemas regionais existentes, o europeu é o mais consolidado e amadurecido, exercendo forte influência sobre os demais - os sistemas interamericano e africano (PIOVESAN, 2006, p. 63). O sistema europeu é o que traduz a mais extraordinária experiência de judicialização de direitos humanos por meio da atuação da Corte Europeia, ou seja, o sistema europeu não somente arrola um catálogo de direitos, mas institui um sistema

23 O Brasil aderiu à Convenção em 25 de setembro de 1992 e que foi promulgada pelo Decreto no 678, de 6 de novembro 1992.

${ }^{24} \mathrm{O}$ art. 26 da Convenção Americana de Direitos Humanos preceitua: "Os Estados-Partes comprometem-se a adotar providências, tanto no âmbito interno como mediante cooperação internacional, especialmente econômica e técnica a fim de conseguir progressivamente a plena efetividade dos direitos que decorrem das normas econômicas, sociais e sobre educação, ciência e cultura, constantes da Carta da Organização dos Estados Americanos, reformada pelo Protocolo de Buenos Aires, na medida dos recursos disponíveis, por via legislativa ou por outros meios apropriados". O artigo foi reproduzido da obra de Valerio Mazzuoli (2010. p. 1005).

25 O Estado brasileiro aderiu ao Protocolo, nos termos do art. 21 do Protocolo Adicional à Convenção Americana sobre Direitos Humanos em matéria de direitos econômicos, sociais e culturais (Protocolo de San Salvador), em 21 de agosto de 1996. Esse documento reforça, no âmbito do Sistema Interamericano de Direitos Humanos, o reconhecimento dos direitos humanos de segunda "geração" ou dimensão, a saber: direito ao trabalho (art. 6ㅇ), direitos sindicais (art. 8ㅇ), direito à previdência social (art. 9o), direito à saúde (art. 10), direito à alimentação (art. 12), direito à educação (art. 13), direito aos benefícios da cultura (art. 14), direitos à constituição e proteção da família (art. 15), direito da criança (art. 16), direito do idoso (art. 17), proteção dos deficientes (art. 18). O "Protocolo de San Salvador" pode ser consultado no seguinte site da internet: <http://www.fd.uc.pt/igc/enciclopedia/documentos/instrumentos_regionais/america/protocolo_convenca o_direitos_economicos.pdf>. Acesso em: 10 set. 2010. 
inédito que permite a proteção judicial dos direitos e liberdades nele previstos. Fábio Konder Comparato (2008, p. 268) consigna que a Convenção Europeia de Direitos Humanos foi celebrada em Roma, em 4 de janeiro de 1950, no âmbito do Conselho da Europa, organização representativa dos Estados da Europa Ocidental, criada em 5 de maio de 1949, a fim de promover a unidade europeia, proteger os direitos humanos e fomentar o progresso econômico e social. Em 18 de outubro de 1961, porém, foi celebrada e adotada, na cidade de Turim, a Carta Social Europeia ao estabelecer e declarar os direitos sociais, econômicos e culturais não constantes na Convenção Europeia de 1950. Esse tratado entrou em vigor em 26 de fevereiro de 1965. Registre-se que, em 1996, a Carta Social Europeia foi revisada e consagrou certo número de direitos novos em matéria social como o direito à dignidade do trabalho, o direito à proteção contra a pobreza e a exclusão social e o direito à moradia (COMPARATO, 2008, p. 269).

Lançando-se o olhar sobre as ordens constitucionais nacionais, reconhece-se, em regra, também uma orientação social, ainda que o quadro opere de modo não uniforme (NEUNER, 2009, p. 21). Assim, podem-se mencionar, exemplificativamente, no círculo jurídico ibero-americano, os pormenorizados catálogos de direitos fundamentais sociais nas constituições do Brasil, de Portugal e da Espanha.

Logo, o reconhecimento internacional dos direitos fundamentais sociais se manifesta não apenas textualmente nos diversos pactos, tratados, declarações e convenções universais e regionais de direitos humanos, mas também em numerosas constituições.

O direito social originou-se das questões entre patrões e operários da grande indústria, da luta operária, da denominada luta de classes. Foi tratado como direito dos trabalhadores, direito dos operários ou como legislação social. O direito social é aquele que se refere à proteção dos indivíduos economicamente enfraquecidos ao ter por finalidade o equilíbrio social, o bem comum, o direito à satisfação das necessidades vitais do indivíduo como membro da coletividade ante um esforço conjunto dos institutos jurídicos para a eficácia e efetividade das normas consagradoras de direitos fundamentais sociais.

O direito social que não elimina o direito individual, mas antes completa o seu âmbito de ação, não está situado fora nem contra o Estado. Nesse sentido, Celso Antônio Bandeira de Mello (1981, p. 235), em lapidar magistério, aponta a relevância e consagração dos direitos sociais, in verbis: 
É sabido e assente que o constitucionalismo do século XX marca-se pela superação da perspectiva inerente ao liberalismo individualista do período clássico. As Constituições, mexicana de 1917 e a de Weimar de 1919, são os primeiros sinais expressivos de um ideário novo, de cunho social, cristalizado nas Cartas Fundamentais.

Nelas está plasmada a concepção de que não basta assegurar os chamados direitos individuais para alcançar-se a proteção do indivíduo. Impende considerá-lo para além de sua dimensão unitária, defendendo-o também em sua condição comunitária, social, sem o que Ihe faltará o necessário resguardo. Isto é, cumpre ampará-lo contra as distorções geradas pelo desequilíbrio econômico da própria sociedade, pois estas igualmente geram sujeições, opressões e esmagamento do indivíduo. Não são apenas os eventuais descomedimentos do Estado que abatem, aniquilam ou oprimem os homens. Tais ofensas resultam, outrossim, da ação dos próprios membros do corpo social, pois podem prevalecer-se e se prevalecem de suas condições socioeconômicas poderosas em detrimento dos economicamente mais frágeis.

A consagração dos direitos individuais corresponde ao soerguimento de uma paliçada defensiva do indivíduo perante o Estado. A consagração dos direitos sociais retrata a ereção de barreiras defensivas do indivíduo perante a dominação econômica de outros indivíduos.

Enquanto os direitos individuais interditam ao Estado o amesquinhamento dos indivíduos, os direitos sociais interditam aos próprios membros do corpo social que deprimam economicamente ou que releguem ao abandono outros indivíduos menos favorecidos pela fortuna.

Antonio Enrique Pérez Luño (2005, p. 86) assinala que o nascimento e paulatino reconhecimento dos direitos sociais, na atualidade, não devem ser interpretados como uma negação dos direitos individuais (civis e políticos), senão como um fator decisivo para redimensionar seu alcance, visto que estes não podem ser concebidos como um atributo do homem isolado que objetiva interesses individuais e egoístas, mas como um conjunto de faculdades do homem ao desenvolver sua existência na esfera comunitária e conforme as exigências do viver social. Nesse sentido, para Antonio Luño (2005, p. 90), os direitos individuais só podem ter justificação se relacionados à comunidade ou aos efeitos da vida social, isto é, como direitos sociais, econômicos e culturais, os quais devem ser promovidos e protegidos com o fim de afirmar a dimensão social da pessoa humana, dotada de valores autônomos, porém ligada de modo inseparável à comunidade onde desenvolve sua existência.

André de Carvalho Ramos (2005, p. 235), na mesma linha de raciocínio expendida pelo autor espanhol acima referido, sustenta que os direitos sociais asseguram as condições para o exercício dos direitos liberais (civis e políticos) e que, em razão disso, a responsabilidade internacional do Estado por violação dos direitos sociais deve expor as 
omissões e fraquezas deste mesmo Estado e obrigá-lo a executar as políticas públicas necessárias à correta concretização destes direitos.

José Ledur (1998, p. 163) leciona que os direitos, de segunda dimensão, surgiram para conferir vitalidade aos direitos de primeira dimensão. ${ }^{26}$ Segundo Ledur (1998, p. 163), os direitos de primeira e segunda dimensão são direitos compatíveis e complementares que se necessitam reciprocamente para terem pretensão de efetividade ao se exigir, portanto, atuação complementar e não excludente.

Do expendido, perfilha-se a concepção contemporânea de direitos fundamentais ao abrangerem os civis e políticos (de cunho liberal) e os direitos sociais, econômicos e culturais em que ambos os grupos desses direitos devem ser concebidos como unidade indivisível, interdependente e inter-relacionada, na qual os valores da igualdade e liberdade se conjugam e se completam. ${ }^{27}$

Considerando-se inadequada a visão dicotômica, pretende-se registrar a necessidade de um tratamento sistêmico dos direitos fundamentais, seja na Constituição portuguesa, seja na Constituição brasileira, e, além disso, apontar algumas de suas consequências para os direitos sociais, partindo-se da existência de uma "unidade de sentido jurídico-constitucionalmente fundada" quanto aos direitos fundamentais. ${ }^{28}$

Esta unidade axiológico-normativa não se reconduz a uma ordem de valores caracterizada por uma hierarquia absoluta, abstrata e fechada; diversamente, concebe-se o sistema dos direitos fundamentais - subsistema do sistema constitucional - como pluralista

26 O autor esclarece, por exemplo, acerca da utilidade de alguém possuir o direito de expressão se não reúne condições, oriundas do acesso à educação básica, para se expressar, e vice-versa. Pode-se observar que as duas categorias de direitos formam vias de mão dupla.

27 Nesse mesmo sentido é o pensamento de Flávia Piovesan (2003, p. 618). Carlos Weis (1999, p. 117-121) adota, também, a compreensão de que todos direitos humanos são indivisíveis, interdependentes e interrelacionados.

28 As ideias expendidas fundamentam-se, sem que se adira a todas as afirmações, nas concepções do expoente jurista lusitano José Carlos Vieira de Andrade (2004, p. 105-111). O autor aduz na página 110: “[...] Os direitos fundamentais não têm sentido nem valem apenas pela vontade (pelo poder) que historicamente os impõe. O conjunto de direitos fundamentais é significativo e desvendável porque é referido a um critério de valor; os direitos fundamentais são obrigatórios juridicamente porque são explicitações do princípio da dignidade da pessoa humana, que lhes dá fundamento. É que a unidade dos direitos fundamentais, como a unidade da ordem jurídica em geral, há de ser uma unidade axiológica, material, que funde e legitime o seu conteúdo normativo. É neste sentido que se defende que o valor da dignidade de cada pessoa, como ser livre e responsável, único e irrepetível, não é um produto ideológico, uma especificidade do liberalismo individualista já perimido, antes corresponde a uma potencialidade característica do ser humano, que se vai atualizando nas ordens jurídicas concretas. [...]”. 
e aberto, correspondente a uma ordem cultural positiva e histórica guiada pela dignidade da pessoa humana.

Ao considerar a Constituição como conjunto normativo superior da ordem jurídica, tomam-se as normas constitucionais como formalmente situadas na mesma posição hierárquica, o que é reforçado pela necessidade de unidade da Constituição.

A aceitabilidade da concepção sistêmica dos direitos fundamentais torna impossível de efetivamente traçar uma linha divisória entre os direitos de liberdade e os direitos sociais.

Paulo Bonavides (2004, p. 642-643) perfilha a compreensão sistêmica e integral entre os direitos de primeira dimensão (direitos individuais) e direitos de segunda dimensão (direitos sociais) não existindo, pois, hierarquia entre eles. O autor, com destreza doutrinal, leciona que

[...] não há distinção de grau nem de valor entre os direitos sociais e os direitos individuais. No que tange à liberdade, ambas as modalidades são elementos de um bem maior já referido, sem o qual tampouco se torna efetiva a proteção constitucional: a dignidade da pessoa humana. Estamos, aqui, em presença do mais alto valor incorporado à Constituição como fórmula universal de um novo Estado Social de Direito. É por essa ótica - a dignidade da pessoa humana - que se guia a diligência interpretativa das presentes reflexões. Garantias sociais são, no melhor sentido, garantias individuais, garantias do indivíduo em sua projeção moral de ente representativo do gênero humano, compêndio da personalidade, onde se congregam os componentes éticos superiores mediante os quais a razão qualifica o homem nos distritos da liberdade, traçando-lhe uma circunferência de livre-arbítrio que é o espaço de sua vivência existencial.

A dignidade da pessoa humana, que aparece na base da ideia de direitos fundamentais, justifica uma compreensão sistêmica destes direitos; se estes são positivações do homem com o objetivo de garantir proteção à dignidade da pessoa humana ao assegurar o pleno desenvolvimento da personalidade, com autodeterminação e liberdade, não se justifica um tratamento estanque, sob pena de se fragmentar o que deve ser pleno - a dignidade - e de não se lograr atingi-lo. Assim, a partir da dignidade humana é possível conferir unidade ao sistema de direitos fundamentais - ainda que seja possível identificar diferentes graus de realização nos diversos direitos fundamentais -, uma vez que impõe deveres ao Estado que não se esgotam em omissões, estendem-se à exigência de prestações positivas, à atuação conformadora do Estado na perseguição de condições materiais concretas (NOVAIS, 2004, p. 52-53; 64-68). 
Pode-se dizer que, além de a dignidade da pessoa humana conferir fundamentalidade aos direitos sociais (de 2 a dimensão), exigindo que compartilhem com os direitos de liberdade ou individuais (de 1a dimensão) desta fundamentalidade, deixa transparecer que os direitos de liberdade, não raras vezes, não lograriam qualquer efetividade ou realização sem os direitos sociais, o que vem reforçar a indivisibilidade dos direitos fundamentais, ou seja, entre direitos de liberdade e direitos sociais.

São indivisíveis, pois todos os direitos fundamentais devem ter a mesma proteção jurídica, visto que são essenciais para uma vida digna. Todos possuem uma composição uniforme ao reconhecer que o direito protegido apresenta uma unidade incindível em si, não pode ser decomposto, separado.

São interdependentes, pois todos os direitos fundamentais estão conexos entre si por uma recíproca dependência. Um direito não alcança a eficácia plena sem a realização simultânea de alguns ou de todos os outros direitos fundamentais. Essa característica não distingue direitos civis e políticos com os direitos sociais, econômicos e culturais, uma vez que a realização de um direito fundamental específico pode depender (como geralmente ocorre) da promoção e concretização de outros direitos fundamentais (WEIS, 1999, p. 118).

São inter-relacionados e complementares de modo que o grupo de direitos fundamentais civis e políticos só pode ter justificação se relacionados com os direitos fundamentais sociais. Para que se tenha uma sociedade efetivamente livre ou que se tenha viabilizado o exercício de suas liberdades fundamentais, é necessário assegurar o pleno desenvolvimento da personalidade humana por meio, por exemplo, de o Estado fornecer saúde, educação, moradia etc. Apenas com o reconhecimento integral de todos os direitos fundamentais torna possível assegurar a existência real de cada um deles, já que sem a efetividade do desfrute dos direitos fundamentais sociais os direitos fundamentais liberais (civis e políticos) se reduzem a meras categorias formais (PIOVESAN, 2003, p. 618). ${ }^{29}$

Sem negar as diferenças entre direitos de liberdade e direitos sociais, urge compreendê-los sistematicamente, unidos pela dignidade da pessoa humana, que torna

\footnotetext{
29 A concepção contemporânea de direitos humanos caracteriza-se pelos processos de universalização e internacionalização destes direitos, compreendidos sob a ótica da indivisibilidade, interdependência e inter-relação. Ressalte-se que a Declaração e Programa de Ação de Viena da Conferência Mundial sobre Direitos Humanos de 1993 reitera a concepção da Declaração Universal de Direitos Humanos de 1948 quando, em seu § 5o, afirma: "Todos os direitos humanos são universais, interdependentes e interrelacionados. A comunidade internacional deve tratar os direitos humanos globalmente de forma justa e equitativa, em pé de igualdade e com a mesma ênfase".
} 
irrecusável a afirmação de que também os direitos sociais são direitos fundamentais ${ }^{30} \mathrm{e}$, assim, devem ser retirados da deliberação da maioria parlamentar, devem ficar ao largo das pressões momentâneas; sua fundamentalidade traduz-se exatamente na sua imposição para os poderes estatais (NOVAIS, 2006, p. 17).

Dimitri Dimoulis e Leonardo Martins (2007, p. 67) pontificam que os chamados direitos sociais ou direitos a prestações encontram-se na categoria dos direitos de status positivus, porquanto permitem ao indivíduo exigir determinada atuação do Estado no intuito de melhorar as condições de vida ao assegurar os pressupostos materiais necessários para o exercício da liberdade, incluindo as liberdades de status negativus (trata-se de direitos que permitem aos indivíduos resistir a uma possível atuação do Estado). O termo direitos sociais se justifica porque seu escopo é a melhoria de vida de extensas categorias da população mediante políticas públicas e medidas concretas de política social. E arrematam ao indicar que os direitos sociais são considerados direitos fundamentais, visto que todos os direitos garantidos na Constituição brasileira são considerados fundamentais, mesmo quando seu alcance e relevância social forem bastante limitados. Ressaltam, enfim, que o termo "direito fundamental" é de sentido idêntico do termo "direito que possui força jurídica constitucional" (DIMOULIS; MARTINS, 2007, p. 54, 67).

Os direitos sociais indicados na Constituição brasileira de 1988 não excluem outros, os quais se agregam ao ordenamento pátrio, seja pela via legislativa ordinária, seja por força da adoção de tratados internacionais. Há que destacar sua abertura, visto que não são numerus clausus. É o que se depreende do próprio caput do artigo 70, o qual declara não estarem excluídos outros direitos sociais que visem à melhoria da condição social dos trabalhadores (TAVARES, 2006, p. 713-714).

Por sua vez, também não se poderia versar acerca de direitos sociais fundamentais sem os relacionar com a passagem do Estado Liberal, consagrado pela dicção francesa

30 Ingo Wolfgang Sarlet (2009, p. 223) firma posição no sentido de que - no âmbito do sistema de direito constitucional positivo brasileiro - todos os direitos, tenham sido expressa ou implicitamente positivados, estejam sediados no Título II da Constituição Federal (Dos Direitos e Garantias Fundamentais) estejam localizados em outras partes do texto constitucional ou nos tratados internacionais regularmente firmados e incorporados pelo Brasil, todos eles são direitos fundamentais. No mesmo sentido, Cristina Queiroz (2006, p. 16, 90) ensina que os direitos sociais configuram-se como direitos fundamentais reconhecidos por normas de estalão constitucional. Para ela, devem ser igualmente constituídos como posições jurídicas jusfundamentais, isto é, como direitos subjetivos. 
laissez-faire, laissez-passer, para o Estado de Bem-Estar Social, da mesma forma conhecida como Welfare State.

Segundo Ingo Wolfgang Sarlet (2007, p. 56), é nesse panorama que se verificará que, sem dúvida, os direitos sociais surgem como direitos fundamentais em face dos reclamos que se fizeram presentes em dada época, em dado momento, em especial devido ao impacto da industrialização e aos graves problemas sociais e econômicos que a acompanharam, às doutrinas socialistas e à constatação de que a consagração formal de liberdade e igualdade não propiciava a garantia do seu efetivo gozo que acabaram, já no decorrer do século XIX, gerando amplos movimentos reivindicatórios (como direitos trabalhistas e direitos à seguridade social, cuja proteção jurídica se reclama), assim como o reconhecimento progressivo de direitos, atribuindo ao Estado comportamento ativo na realização da justiça social.

Os direitos sociais, todos eles, independentemente da forma de sua manifestação como prestação, têm por finalidade a criação e a garantia de uma igualdade entre os indivíduos e, por isso, de uma liberdade material (e não somente formal). São direitos que buscam, pois, a justiça social (CARVALHO, 2011, p. 189).

Assim, o vocábulo - direitos sociais - é utilizado comumente para significar a tutela de bens jurídicos que visam ao alcance da justiça social. ${ }^{31}$

\section{Direito fundamental à alimentação e sua proteção no plano internacional e nas Constituições}

O direito fundamental à alimentação deve ser percebido não apenas como uma responsabilidade local ou regional, mas deve transpor esses limites ao abranger uma responsabilidade internacional, sobretudo porque se trata de um direito de alcance universal. Com a globalização, os impactos nefastos decorrentes da não realização desse

31 Paulo Bonavides (2004, p. 642) sustenta o seguinte: “[...] A observância, a prática e a defesa dos direitos sociais, a sua inviolável contextura formal, premissa indeclinável de uma construção material sólida desses direitos, formam hoje o pressuposto mais importante com que fazer eficaz a dignidade da pessoa humana nos quadros de uma organização democrática da Sociedade e do Poder. [...] Sem a concretização dos direitos sociais não se poderá alcançar jamais 'a Sociedade livre, justa e solidária', contemplada constitucionalmente como um dos objetivos fundamentais da República Federativa do Brasil (art. 3ㅇ). 0 mesmo tem pertinência com respeito à redução das desigualdades sociais, que é, ao mesmo passo, um princípio da ordem econômica e um dos objetivos fundamentais de nosso ordenamento republicano, qual consta respectivamente no art. 170, VII, e do sobredito art. 3 ” ". 
direito não se circunscreve ao plano nacional, mas se irradiam por todos os continentes. Nesse diapasão, a responsabilidade pelo direito fundamental à alimentação sobressai em vários instrumentos internacionais de proteção dos direitos fundamentais, de âmbito global e regional, ${ }^{32}$ fruto da internacionalização destes direitos.

O direito à alimentação constitui um direito fundamental básico, estabelecido e consagrado em vários documentos internacionais tais como declarações, pactos e convenções ao adotarem a premissa de que todos os direitos fundamentais são universais, indivisíveis, interdependentes e inter-relacionados, cuja validade é perene, sendo a intransponibilidade, um requisito essencial. Em razão da indivisibilidade dos direitos fundamentais, Flávia Piovesan (2007, p. 25-26) afirma que não há direitos fundamentais sem que os direitos econômicos, sociais e culturais estejam garantidos e que, por isso, devem ser reivindicados como direitos, e não como caridade, generosidade ou compaixão. Ainda, conforme escólio da mencionada autora, fundamenta seu pensamento no sentido de que:

Levar os direitos econômicos, sociais e culturais a sério implica, ao mesmo tempo, um compromisso com a integração social, a solidariedade e a igualdade, incluindo a questão da distribuição de renda. Os direitos sociais, econômicos e culturais incluem como preocupação central a proteção a grupos vulneráveis. [...] As necessidades fundamentais não devem ficar condicionadas à caridade de programas e políticas estatais, mas devem ser definidas como direitos (PIOVESAN, 2007, p. 26).

32 Destacam-se alguns instrumentos internacionais (declarações, pactos e convenções) de inegável importância, a saber: além da Declaração Universal dos Direitos Humanos (1948) e do Pacto Internacional dos Direitos Econômicos, Sociais e Culturais (1966), tem-se a Declaração das Nações Unidas dos Direitos dos Portadores de Deficiência (1975) que proclamou o tema da alimentação como direito. Nas previsões da Convenção sobre a Eliminação de Todas as Formas de Discriminação contra as Mulheres (1979), na Declaração sobre o Direito ao Desenvolvimento (1986) que assegurou o direito à alimentação. A Declaração dos Direitos da Criança (1959) e a Convenção das Nações Unidas sobre os Direitos da Criança (1989) reconheceram o direito de toda a criança ter um padrão de vida adequado ao seu desenvolvimento físico, mental, espiritual, moral e social. A Convenção no 169 da Organização Internacional do Trabalho (1989) concernente aos povos e às tribos indígenas em países, também proclama o direito à alimentação. Outras reuniões, documentos e cúpulas internacionais também trataram do tema: Conferência Mundial sobre Alimentação (1974), Declaração de Princípios e Programas de Ação da Conferência Mundial sobre Reforma Agrária e Desenvolvimento Rural (1979), Conferência Internacional sobre Nutrição (1992), Declaração e Programa de Ação de Viena da Conferência Mundial sobre Direitos Humanos (1993), Declaração e Programa de Ação da Cúpula Mundial para o Desenvolvimento Social-Copenhague (1995), Conferência de Pequim sobre a Mulher (1995), Declaração de Roma sobre Segurança Alimentar e o Plano de Ação da Cúpula Mundial de Alimentação (1996) e a Declaração do Milênio das Nações Unidas (2000). No plano regional tem-se o Protoco de San Salvador, protocolo adicional à Convenção Americana sobre Direitos Humanos (1969), que no art. 12 estabelece que "todos têm direito à adequada nutrição que garanta possibilidade de gozar do maior nível de desenvolvimento físico, emocional e intelectual". Por sua vez, no espaço eurocomunitário tem-se a Carta Social Europeia que foi revista em 1996. 
A consagração e o reconhecimento internacional de um direito fundamental à alimentação encontra-se assinalado na Declaração Universal dos Direitos Humanos, que é marco da criação do Direito Internacional dos Direitos Humanos. ${ }^{33}$ Ela versou sobre o direito à alimentação de forma mais ampla e o tratou como integrante do direito a um padrão de vida que pudesse assegurar saúde e bem-estar. ${ }^{34}$

Seja por fixar a ideia de que os direitos humanos são universais, decorrentes da dignidade da pessoa humana e não derivados das peculiaridades sociais e culturais de determinada sociedade, seja por incluir em seu elenco não só direitos civis e políticos, mas também sociais, econômicos e culturais, a Declaração Universal de 1948 demarca a concepção contemporânea dos direitos humanos.

A Declaração Universal de Direitos Humanos tem sido concebida como interpretação autorizada da expressão "direitos humanos e liberdades fundamentais", constante da Carta das Nações Unidas, apresentando, por esse motivo, força jurídica vinculante, embora seja somente uma recomendação das Nações Unidas, adotada sob a forma de resolução de sua Assembleia-Geral, que consubstancia uma ética universal em relação à conduta dos Estados no que tange à proteção internacional dos direitos humanos. Os Estados-membros das Nações Unidas (atualmente são 193) ) $^{35}$ têm, assim, a obrigação de promover o respeito e a observância universal dos direitos proclamados pela Declaração.

33 A aprovação pela Assembleia Geral das Nações Unidas da Declaração Universal de Direitos humanos pela Resolução 217-A (III), em 10 de dezembro de 1948, constitui o principal feito no desenvolvimento da ideia contemporânea de direitos humanos (ou fundamentais), bem como a Convenção Internacional sobre a prevenção e punição do crime de genocídio aprovada um dia antes, também no quadro da ONU; logo, ambas formam os marcos inaugurais da nova fase histórica dos direitos humanos que se encontra em pleno desenvolvimento. O texto da Declaração Universal dos Direitos Humanos (DUDH) pode ser visto em: <http://www.unhchr.ch/udhr/lang/por.htm>.

34 Artigo 22. "Todo ser humano, como membro da sociedade, tem direito à segurança social e à realização, pelo esforço nacional, pela cooperação internacional e de acordo com a organização e recursos de cada Estado, dos direitos econômicos, sociais e culturais indispensáveis à sua dignidade e ao livre desenvolvimento da sua personalidade". O artigo 25 traz o seguinte reforço: "1. Todo ser humano tem direito a um padrão de vida capaz de assegurar a si e a sua família saúde e bem-estar, inclusive alimentação, vestuário, habitação, cuidados médicos e os serviços sociais indispensáveis, e direito à segurança em caso de desemprego, doença, invalidez, viuvez, velhice ou outros casos de perda dos meios de subsistência fora de seu controle. 2. A maternidade e a infância têm direito a cuidados e assistência especiais. Todas as crianças nascidas dentro ou fora do matrimônio, gozarão da mesma proteção social”. A Declaração Universal dos Direitos Humanos foi adotada e proclamada pela resolução 217-A (III) da Assembleia Geral das Nações Unidas em 10 de dezembro de 1948. Disponível em: <http://www.ohchr.org/EN/UDHR/Pages/UDHRIndex.aspx>. Acesso em: 5 jan. 2012.

35 Informação haurida do site da ONU. Disponível em: <http://www.un.org/en/>. Acesso em: 20 jan. 2012. 
Nesse sentido estabelece o art. 28 da Declaração que todos têm direito a uma ordem social e internacional em que os direitos e liberdades sejam plenamente realizados.

A necessidade de explicitar com maior precisão e detalhamento os direitos constantes na Declaração Universal dos Direitos Humanos ao tornar seus dispositivos em previsões juridicamente vinculantes e obrigatórios, a Assembleia Geral das Nações Unidas aprovou, em 1966, nomeadamente, o Pacto Internacional dos Direitos Civis e Políticos (PIDCP) e o Pacto Internacional dos Direitos Econômicos, Sociais e Culturais (PIDESC), ambos conhecidos como Pactos de Nova York. ${ }^{36}$ Nesse momento, o direito à alimentação tornouse pauta específica do PIDESC que determinou o seguinte:

\section{ARTIGO 11}

1. Os Estados-partes do presente Pacto reconhecem o direito de toda pessoa a nível de vida adequado para si próprio e sua família, inclusive à alimentação, vestimenta e moradia adequadas, assim como a uma melhoria contínua de suas condições de vida. Os Estados Partes tomarão medidas apropriadas para assegurar a consecução desse direito, reconhecendo, nesse sentido, a importância essencial da cooperação internacional fundada no livre consentimento.

2. Os Estados-partes do presente Pacto, reconhecendo o direito fundamental de toda pessoa de estar protegida contra a fome, adotarão, individualmente e mediante cooperação internacional, as medidas, inclusive programas concretos, que se façam necessárias para:

a) Melhorar os métodos de produção, conservação e distribuição de gêneros alimentícios pela plena utilização dos conhecimentos técnicos e científicos, pela difusão de princípios de educação nutricional e pelo aperfeiçoamento ou reforma dos regimes agrários, de maneira que se assegurem a exploração e a utilização mais eficazes dos recursos naturais;

b) Assegurar uma repartição equitativa dos recursos alimentícios mundiais em relação às necessidades, levando-se em conta os problemas tanto dos países importadores quanto dos exportadores de gêneros alimentícios.

O Comitê de Direitos Econômicos, Sociais e Culturais (CDESC $)^{37}$ das Nações Unidas, responsável por monitorar e dar cumprimento ao PIDESC, em seu Comentário Geral de no

36 Conforme última atualização no portal da Nações Unidas (United Nations - Treaty Collection), em janeiro de 2012, o PIDCP compreendia 167 Estados-partes, enquanto o PIDESC abrangia 160 Estados-partes. Acerca do status de cada tratado, convenção ou pacto firmado no âmbito do sistema global de proteção dos direitos humanos, nomeadamente, quanto à entrada em vigor, o rol dos Estados-partes e aqueles que apresentaram reservas poderá ser consultado no site <http://treaties.un.org/Pages/Treaties.aspx?id=4\&subid=A\&lang=en>.

37 O Comitê de Direitos Econômicos, Sociais e Culturais (CDESC) é o órgão que supervisiona o cumprimento do Pacto Internacional de Direitos Econômicos, Sociais e Culturais (PIDESC) por meio da elaboração de relatórios ou pareceres com conclusões e recomendações para os Estados. Não está previsto no Pacto, senão que foi criado pela Resolução 1985/17, de 28 de Maio de 1985, do Conselho Econômico e Social (ECOSOC) das Nações Unidas para o desempenho das funções apresentadas na parte IV do Pacto (artigos 16 a 25$)$. 
$12,{ }^{38}$ de 12 de maio de 1999 (em sua vigésima sessão), discorreu sobre o direito a uma alimentação adequada, tema disciplinado no artigo 11 do PIDESC, dando-lhe os contornos conceituais e estabelendo os meios para a sua realização e fruição. O Comitê trata do conteúdo essencial do direito à alimentação adequada ao fornecer elementos que incorporem a ideia de adequação e sustentabilidade do acesso e da disponibilidade de alimento, e, por essa razão, estabelece que "direito humano à alimentação adequada é de importância crucial para a fruição de todos os direitos".

Além disso, o Comitê realça as obrigações dos Estados de adotar ações concretas para que se alcance a total realização do direito fundamental à alimentação. Estas obrigações, no âmbito dos direitos econômicos, sociais e culturais, nomeadamente o acesso ao direito fundamental à alimentação, compreendem a obrigação de respeitar, que obsta que os Estados bloqueiem ou impeçam esse acesso; obrigação de proteger, ao caber aos Estados que evitem que empresas ou indivíduos possam privar outros indivíduos de seu acesso à alimentação adequada; a obrigação de realizar, efetivar (satisfazer) ao requerer dos Estados a adoção de medidas destinadas à realização do direito fundamental à alimentação.

Ainda, especificamente quanto ao direito fundamental à alimentação, o Comitê, em seu Comentário Geral no 12, afirma que esse direito é indivisivelmente vinculado à dignidade inerente à pessoa humana e é indispensável para a realização de outros direitos humanos consagrados na Carta Internacional de Direitos Humanos. Ele é também inseparável da justiça social, requerendo a adoção de políticas econômicas, ambientais e sociais, tanto no âmbito nacional como internacional, orientadas para a erradicação da pobreza e a realização de todos os direitos humanos para todos.

O direito à alimentação deve ser compreendido, na esteira do pensamento de Flávio Valente (2002, p. 38), como o acesso de todos os seres humanos "[...] aos recursos $e$ aos meios para produzir ou adquirir alimentos seguros e saudáveis que possibilitem uma alimentação de acordo com os hábitos e práticas alimentares de sua cultura, de sua região e de sua origem étnica". 38 Os comentários gerais adotados por órgãos de tratado da ONU possuem o condão de harmonizar o
desenvolvimento da legislação de direitos humanos. 
É com esses parâmetros que o Comitê, em seu Comentário Geral no 12, sobretudo ao interpretar o artigo 11, parágrafos 1으 e 2 ㅇ do PIDESC, apresenta o conteúdo normativo da ideia de um direito fundamental à alimentação ao afirmar que este somente será alcançado quando todos os homens, mulheres e crianças, sozinhos ou em companhia com outros, têm acesso físico e econômico, ininterruptamente, à alimentação adequada ou aos meios para sua obtenção. Impende destacar que o significado de alimentação adequada refere-se não apenas às calorias, proteínas e outros nutrientes, mas, também, às condições sociais, econômicas, culturais, climáticas e ecológicas.

Um organismo internacional de inegável importância é a Organização das Nações Unidas para Agricultura e Alimentação (Food and Agriculture Organization of the United Nations - FAO). Criada em 16 de outubro de 1945, a FAO atua como um fórum neutro, onde todos os países, desenvolvidos e em desenvolvimento, se reúnem em igualdade para negociar acordos, debater políticas e impulsionar iniciativas estratégicas. Atualmente a FAO tem 191 países membros, mais a Comunidade Europeia. A rede mundial compreende cinco oficinas regionais e 78 escritórios nacionais. Como agência especializada das Nações Unidas, ela trabalha no combate à fome e à pobreza, promove o desenvolvimento agrícola, a melhoria da nutrição, a busca da segurança alimentar e o acesso de todas as pessoas, em todos os momentos, aos alimentos necessários para uma vida saudável. Reforça a agricultura e o desenvolvimento sustentável, como estratégia a longo prazo, para aumentar a produção e o acesso de todos aos alimentos, ao mesmo tempo em que preserva os recursos naturais.

O ano de 1996, com a realização da primeira Cúpula Mundial sobre a Alimentação presidida pela FAO, na cidade de Roma, constituiu o marco mundial com a preocupação da segurança alimentar no mundo. Estiveram presentes representantes de 185 países mais a Comunidade Europeia que se reuniram para discutir a fome do mundo e, num ato protocolar, comprometeram-se a erradicar a fome de todos os países, tendo como objetivo imediato o de reduzir pela metade, até 2015, o atual número de pessoas desnutridas. Ficava então instalada a Declaração de Roma sobre Segurança Alimentar. As raízes intrínsecas desse ato foram motivadas pela situação intolerável, quando 800 milhões de pessoas não tinham alimento suficiente para satisfazer suas necessidades nutricionais básicas. Reafirmaram o direito à alimentação adequada e o direito básico de todos estarem livres da 
fome. A realização e a implementação do direito à alimentação adequada deve ser objeto central de todos os Estados e de outros atores, a fim de erradicar a fome e a desnutrição (MANIGLIA, 2009, p. 125).

O direito à alimentação está estreitamente ligado à ideia de segurança alimentar. A segurança alimentar era outrora compreendida como uma política de armazenamento estratégico e de oferta segura e adequada de alimentos, e não como um direito de todo ser humano a ter acesso a uma alimentação saudável. O enfoque estava no alimento, e não no ser humano. Com o aumento da produção de alimentos, nos fins da década de 1970, o mundo despertou para a realidade e passou a encarar a situação da fome e desnutrição como um problema realmente de acesso e não de produção. $\mathrm{O}$ aumento da população deixou de ser preocupante, já que havia meios de produzir ante os avanços tecnológicos constantes (MANIGLIA, 2009, p. 126).

Já em 1983, a FAO apresentou um novo conceito de segurança alimentar ao se basear em três objetivos: (a) oferta adequada de alimentos; (b) estabilidade da oferta e dos mercados de alimentos; (c) segurança no acesso aos alimentos ofertados. A partir de 1990, já com a questão da sustentabilidade em discussão simultânea com o meio ambiente, mais uma modificação foi feita ao significado de segurança alimentar. Englobaram-se ao seu conteúdo: (a) noções de alimento seguro; (b) qualidade do alimento; (c) balanceamento da dieta; (d) informação sobre os alimentos; (e) opções de hábitos alimentares em modos de vida (MANIGLIA, 2009, p. 125).

Consigna-se que na Declaração de Roma sobre a Segurança Alimentar Mundial e o Plano de ação da Cúpula Mundial da Alimentação, em 1996, os Chefes de Estado e de Governo ou com os seus respectivos representantes reafirmaram o direito de todos a terem acesso a alimentos seguros e nutritivos em consonância com o direito a uma alimentação adequada e com o direito fundamental de todos a não sofrer de fome. Além disso, comprometeram-se com vontade política a atingir uma segurança alimentar para todos, bem como a realização de um esforço permanente para erradicar a fome em todos os países.

Afirmaram, ainda, o compromisso de se empenharem ao levar a cabo o Plano de Ação da Cúpula Mundial da Alimentação (1996) que, no seu primeiro parágrafo, delineia o sentido de segurança alimentar, in verbis: "[...] Existe segurança alimentar quando as 
pessoas têm, a todo o momento, acesso físico e econômico a alimentos seguros, nutritivos e suficientes para satisfazer as suas necessidades dietéticas ${ }^{39}$ e preferências alimentares, a fim de levarem uma vida saudável e ativa" (FAO, 1996). Posteriormente a esse período, a segurança alimentar passou a ser entendida como um direito fundamental básico à alimentação e nutrição.

É evidente que o alcance de um bom estado nutricional não depende somente da segurança alimentar, mas também do acesso a outras condições para uma vida saudável como moradia, abastecimento e acesso de água potável, condições sanitárias, acesso aos serviços de saúde, educação etc.

A Cúpula Mundial da Alimentação sobre Segurança Alimentar, ou a "Cúpula da Fome" realizada em novembro de 2009, adotou a declaração (Declaração da Cúpula Mundial sobre Segurança Alimentar - 2009) renovando o compromisso feito na Cúpula Mundial da Alimentação de 1996 de erradicar a fome de forma sustentável da face da terra. A Declaração também menciona a necessidade de um aumento no fundo para agricultura nacional e internacional, novos investimentos no setor rural, melhoria da administração das questões globais em parceria com os atores interessados dos setores público e privado, e maior ação para enfrentar a ameaça que a mudança climática representa para a segurança alimentar.

No Brasil, a partir da realização da 1a Conferência Nacional de Alimentação e Nutrição $(1986)^{40}$ e das Conferências Nacionais de Segurança Alimentar e Nutricional (II CNSAN - 2004 e III CNSAN - 2007), ${ }^{41}$ fortaleceu-se o princípio da alimentação como um direito de cidadania, no horizonte dos desdobramentos específicos da Constituição brasileira

39 Conforme Comentário Geral no 12, do Comitê de Direitos Econômicos, Sociais e Culturais (CDESC), por necessidades dietéticas "entende-se que a dieta, como um todo, deva conter uma mistura de nutrientes necessários para o crescimento físico e mental, desenvolvimento e manutenção, e atividade física, que estejam de acordo com as necessidades fisiológicas humanas em todas as etapas do ciclo de vida, e de acordo com o gênero e a ocupação. É possível que medidas precisem ser tomadas para manter, adaptar ou fortalecer a diversidade dietética e os padrões de consumo e administração dos alimentos, o que inclui a amamentação, ao mesmo tempo em que se assegura que mudanças na disponibilidade e acessibilidade aos alimentos pelo menos não afetem negativamente a composição da dieta e o consumo".

40 A importância desse evento se destaca pelo fato de lançar um conjunto de proposições que se tornaram referências para lutas posteriores, a saber, a incorporação do adjetivo "nutricional" no conceito de segurança alimentar, a necessidade de um Conselho Nacional de Alimentação e Nutrição que formulasse a Política Nacional de Segurança Alimentar e a adoção de um Sistema Nacional de Segurança Alimentar e Nutricional.

41 A Conferência Nacional de Segurança Alimentar é o espaço em que representantes governamentais e da sociedade civil de todo o país reunir-se-ão para a reflexão, discussão, aprendizado e deliberação em torno da segurança alimentar. 
de 1988. Um marco importante na legislação brasileira foi a sanção da lei que instituiu a renda básica de cidadania (Lei no 10.835/2004). Outro passo significativo foi a sanção da Lei Orgânica de Segurança Alimentar e Nutricional (LOSAN) - Lei no 11.346/2006, de 15 de setembro de 2006 -, que incorpora os princípios dos instrumentos internacionais sobre o direito fundamental à alimentação já referidos (universalidade, indivisibilidade, inalienabilidade, interdependência e inter-relacionariedade), e cria o Sistema Nacional de Segurança Alimentar e Nutricional (SISAN) ao visar assegurar o direito fundamental à alimentação e estabelecer um conjunto de definições com diretrizes, princípios, objetivos e a própria composição do SISAN. A Lei no 11.346/2006, a LOSAN, preceitua no seu artigo 2은 que:

\begin{abstract}
A alimentação adequada é um direito fundamental do ser humano, inerente à dignidade da pessoa humana e indispensável à realização dos direitos consagrados na Constituição Federal, devendo o poder público adotar as políticas e ações que se façam necessárias para promover e garantir a segurança alimentar e nutricional da população.
\end{abstract}

Deve-se ressaltar que o direito fundamental à alimentação era tão somente previsto e disciplinado explicitamente em legislação infraconstitucional, não existindo sua consagração no catálogo de direitos fundamentais na Constituição brasileira de 1988. Foi, então, criada uma frente parlamentar para que pudesse ser incluída expressamente o direito à alimentação como direito fundamental social no rol dos direitos e garantias fundamentais na atual Constituição brasileira. Originaram-se duas Propostas de Emenda à Constituição (PEC) sob os números 47/2003 e 64/2007 de autoria, respectivamente, do Senador Antônio Carlos Valadares (PSB/SE) e do Deputado Federal Nazareno Fonteles (PT/PI) com o intuito de inserir o direito fundamental à alimentação no rol dos direitos sociais do artigo 60 da Constituição. Em 4 de fevereiro de 2010, por meio da promulgação da Emenda Constitucional no 64/2010, ao alterar o artigo 6 da Constituição introduziu, enfim, o direito à alimentação como direito fundamental social. ${ }^{42}$

Tal inserção no texto constitucional brasileiro constitui um genuíno marco para o seu reconhecimento formal no catálogo de direitos fundamentais ao afirmar, portanto, a sua

42 A nova redação do artigo 60 da Constituição brasileira de 1988 se apresenta nestes termos: "Art. 60 - São direitos sociais a educação, a saúde, a alimentação, o trabalho, a moradia, o lazer, a segurança, a previdência social, a proteção à maternidade e à infância, a assistência aos desamparados, na forma desta Constituição". 
natureza de direito fundamental por anunciar norma de importância suprema que delinea direito indispensável à concretização da dignidade da pessoa humana, tendo tal direito reconhecimento em diversos documentos internacionais acima especificados, nos quais o Brasil é signatário.

Além do Brasil que consagrou com a EC no 64/2010 o direito fundamental à alimentação em sua Constituição (art. 6o, caput), há um número crescente de Estados em várias partes do mundo que explicitamente inseriram o direito fundamental à alimentação ao garanti-lo e protegê-lo em suas respectivas constituições. A Guatemala encabeçou este movimento ao incluir o direito fundamental à alimentação e nutrição no artigo 99 da sua Constituição de 1985. A Constituição guatemalteca entrou em vigor em 14 de janeiro de 1986 e constitucionalizou o direito fundamental à alimentação e nutrição ao dotá-lo de autonomia própria como direito social. ${ }^{43} \mathrm{O}$ referido artigo da Constituição da República da Guatemala apresenta a seguinte dicção, in verbis:

Artigo 99 - Alimentação e nutrição. O Estado assegurará que a alimentação e nutrição da população reúna os requisitos mínimos de saúde. As instituições especializadas do Estado deverão coordenar suas ações entre si ou com organismos internacionais dedicados à saúde para alcançar um sistema alimentar efetivo. ${ }^{44}$

Em razão dessa consagração na Constituição guatemalteca, acena-se, portanto, para o processo de reconhecimento formal do direito fundamental à alimentação também em outros textos constitucionais. Deve-se apontar, em tal caso, a histórica Constituição da África do Sul, de 1996, ao ir no encalço de introduzir, também, o direito à alimentação no artigo 27 da sua Constituição após o implacável regime de apartheid. Ademais, outros países estão agora se movendo nesta mesma direção. A nova Constituição da República do Quênia, aprovada por um referendo popular em 2010 afirma, no seu art. 43, que "Toda pessoa tem o direito: (a) ao mais alto nível de saúde [...]; (b) a uma habitação acessível e

${ }^{43}$ O direito fundamental à alimentação e nutrição foi positivado dentro do Título II - Direitos Humanos, no Capítulo II - Direitos Sociais, e inscrito na Seção sétima - Saúde, Seguridade e Assistência Social. A Constituição da Guatemala pode ser consultada no seguinte site a fim de ter acesso ao seu texto integral: <http://pdba.georgetown.edu/constitutions/guate/guate.html>.

44 Tradução nossa. O texto original apresenta a seguinte linguagem: "ARTICULO 99 - Alimentación y nutrición. El Estado velará porque la alimentación y nutrición de la población reúna los requisitos mínimos de salud. Las instituciones especializadas del Estado deberán coordinar sus acciones entre sí o con organismos internacionales dedicados a la salud, para lograr un sistema alimentario nacional efectivo". 
adequada e razoáveis padrões de saneamento; (c) a estar livre da fome, e ter uma alimentação adequada de qualidade aceitável; (d) à água limpa e segura em quantidades adequadas $[. . .]^{\prime \prime}{ }^{45} \mathrm{E}$, como da África do Sul, a Constituição queniana impõe o dever de respeitar, proteger, promover e cumprir esse direito.

Em 13 de outubro de 2011, o processo de reforma constitucional foi concluído no México, inserindo o direito à alimentação na Constituição ao alterar, pois, os artigos 4ํ e 27. ${ }^{46} \mathrm{Na}$ Ásia, a Constituição Provisória do Nepal (2007) reconhece um direito fundamental à soberania alimentar (art. 18.3). Outros países cujas constituições explicitamente garantem o direito fundamental à alimentação abrangem a Bolívia (art. 16), Equador (art. 13), Guiana (art.40), Haiti (art. 22) e Nicarágua (art. 63).

É necessário que os direitos fundamentais sejam reconhecidos e minimamente assegurados, caso contrário não haverá espaço para a dignidade da pessoa humana, visto que a concretização deste superprincípio pressupõe a realização, a efetivação do direito fundamental à alimentação. Em consonância com o escólio de Cármen Lúcia Antunes Rocha (1999) acerca da dignidade da pessoa como princípio chave do constitucionalismo contemporâneo aduz que:

\begin{abstract}
o princípio da dignidade da pessoa humana tornou-se, então, valor fundante do sistema no qual se alberga, como espinha dorsal da elaboração normativa, exatamente os direitos fundamentais do homem. Aquele princípio converteu-se, pois, no coração do patrimônio jurídico-moral da pessoa humana estampado nos direitos fundamentais acolhidos e assegurados na forma posta no sistema constitucional. [...] A constitucionalização do princípio da dignidade da pessoa humana modifica, em sua raiz, toda a construção jurídica: ele impregna toda a elaboração do Direito, porque ele é o elemento fundante da ordem constitucionalizada e posta na base do sistema. Logo, a dignidade da pessoa humana é princípio havido como superprincípio constitucional, aquele no qual se fundam todas as escolhas políticas estratificadas no modelo de Direito plasmado na formulação textual da Constituição.
\end{abstract}

45 Tradução nossa. A nova Constituição da República do Quênia foi promulgada em 27 de agosto de 2010. O texto da Constituição do Quênia pode ser compulsada no seguinte site: <http://www.kenyalaw.org/kIr/fileadmin/pdfdownloads/Constitution_of_Kenya_2010.pdf>.

46 O texto constitucional mexicano, com a reforma empreendida em $201 \overline{1}$ nos artigos 40 e 27, apresenta a seguinte redação, conforme se transcreve. Art. 40 - § 3: "Toda persona tiene derecho a la alimentación nutritiva, suficiente y de calidad. El Estado lo garantizará". § 70: "En todas las decisiones y actuaciones del Estado se velará y cumplirá con el principio del interés superior de la niñez, garantizando de manera plena sus derechos. Los niños y las niñas tienen derecho a la satisfacción de sus necesidades de alimentación, salud, educación y sano esparcimiento para su desarrollo integral. Este principio deberá guiar el diseño, ejecución, seguimiento y evaluación de las políticas públicas dirigidas a la niñez". Art. 27, XX, § 20: "El desarrollo rural integral y sustentable a que se refiere el párrafo anterior, también tendrá entre sus fines que el Estado garantice el abasto suficiente y oportuno de los alimentos básicos que la ley establezca". 


\subsection{Direito à alimentação: um direito fundamental autônomo ?}

A previsão expressa do direito à alimentação em documentos internacionais, na Constituição brasileira e em legislação infraconstitucional de alguns países (brasileira, moçambicana, nicaraguense, venezuelana, por exemplo) conduz-se a afirmar, no plano da dogmática jurídica, de um reconhecimento autônomo do direito fundamental à alimentação.

A fundamentalização formal do direito à alimentação como direito fundamental social no art. 60 da Constituição brasileira de 1988, bem como seu reconhecimento explícito no art. 25 da Declaração Universal dos Direitos Humanos e no art. 11 do Pacto Internacional dos Direitos Econômicos, Sociais e Culturais (PIDESC), indiscutivelmente, pretendeu erigir o direito à alimentação um bem jusfundamental primário, um direito que integra, portanto, a segunda dimensão dos direitos fundamentais. Agora, constitui um bem diretamente estatuído da norma jusfundamental ao ampliar o catálogo de direitos fundamentais, sendo imprescindível para a promoção e concretização da dignidade da pessoa humana.

A fundamentalização material ${ }^{47}$ do direito à alimentação deriva do fato de ele estar intimamente identificado com o superprincípio da dignidade da pessoa humana.

Não se perfilha a posição que aduz que o direito à alimentação ser tipicamente uma decorrência do direito à vida ou, ainda, marcadamente derivado do direito à saúde. Pelo contrário, a preservação do direito à vida e do direito à saúde só pode ter sentido quando se proclama, protege, concretiza, garante o direito fundamental à alimentação, pois sem a realização e o acesso a este direito ao ter como fundamento a dignidade da pessoa humana, não seria exequível propugnar o direito de continuar vivo, nem mesmo o alcance do bemestar da humanidade.

O alimento é o combustível capaz de produzir a energia indispensável à vida e à saúde humanas. Sem a ingestão de alimentos ou um consumo menor de nutrientes, a produção necessária de energia se estagnará com a consequente ausência de metabolismo em qualquer organismo vivo ao repercutir, portanto, negativamente na sobrevivência do ser

47 Em um sentido material, a fundamentalidade dá ênfase ao conteúdo dos direitos. Assim, se o direito, em razão de seu conteúdo, é indispensável para a constituição e manutenção das estruturas básicas do Estado e da sociedade, sobretudo no que refere à posição neles ocupada pela pessoa, ele é fundamental, independentemente de ser constitucionalizado. A ideia de fundamentalidade material pode estar ou não associada à constituição escrita. Ela decorre da circunstância de serem os direitos fundamentais elemento decisivamente constitutivo da Constituição material ao conter decisões fundamentais sobre a estrutura básica do Estado e da sociedade. Os direitos materialmente fundamentais são identificados pelo conteúdo comum baseado no superprincípio da dignidade da pessoa humana. 
humano. Assim, ao ter em vista a proteção da vida e da saúde do homem se requer o acesso aos alimentos, sobretudo o direito de estar livre da fome com a adequada quantidade e qualidade nutricional granjeada pelos indivíduos.

\subsection{O regime de eficácia aplicado ao direito fundamental à alimentação na experiência constitucional brasileira e no âmbito do PIDESC}

Conforme dispõe o art. 5으 $\S 1$ 으 da Constituição brasileira de 1988: "As normas definidoras dos direitos e garantias fundamentais têm aplicação imediata". Essa previsão consiste impor aos poderes públicos a incumbência da tarefa e do dever de extrair das normas que os consagram (de todos os direitos fundamentais, até mesmo os não previstos no catálogo, como os constantes do título II, da CRFB/1988, a maior eficácia possível outorgando-Ihes, neste sentido, efeitos reforçados relativamente às demais normas constitucionais que, segundo Ingo Wolfgang Sarlet (2007, p. 285-286), não há como desconsiderar a circunstância de que a presunção da aplicabilidade imediata e plena eficácia que milita em favor dos direitos fundamentais constitui, em verdade, um dos esteios de sua fundamentalidade formal no âmbito da Constituição. Assim, de acordo com o citado jurista, para além da aplicabilidade e eficácia imediata de toda a Constituição, na condição de ordem jurídico-normativa, percebe-se que o art. 5으, § 1이 da Constituição Federal constitui, na verdade, um plus agregado às normas definidoras de direitos fundamentais, que tem por finalidade a de ressaltar a sua aplicabilidade imediata independentemente de qualquer medida concretizadora.

Nesse sentido, percebe-se, desde logo, que o Constituinte, de acordo com Ingo Wolfgang Sarlet, não pretendeu excluir do âmbito do art. 5으, § 10 da CF/1988, os direitos políticos, de nacionalidade e os direitos sociais, cuja fundamentalidade parece inquestionável. Também não há como sustentar, no direito pátrio, a concepção lusitana (lá expressamente prevista na Constituição) de acordo com a qual a norma que consagra a aplicabilidade imediata dos direitos fundamentais abrange apenas os direitos, liberdades e garantias (Título II da CRP) que, em princípio, correspondem aos direitos de defesa, excluindo deste regime reforçado (e não apenas quanto a este aspecto) os direitos 
econômicos, sociais e culturais do Título III da Constituição portuguesa. ${ }^{48}$ A Constituição brasileira não estabeleceu distinção desta natureza entre os direitos de liberdade e os direitos sociais, encontrando-se todas as categorias de direitos fundamentais sujeitas, em princípio, ao mesmo regime jurídico (SARLET, 2007, p. 275).

Flávia Piovesan (2006, p. 35) consigna que o princípio da aplicabilidade imediata de todos os direitos fundamentais realça a força normativa que eles detêm, prevendo tal princípio um regime jurídico específico endereçado a todos os preceitos constitucionais referentes aos direitos fundamentais. Para Piovesan (2006, p. 35-36), cabe aos poderes públicos conferir eficácia máxima e imediata a todo e qualquer preceito definidor de direito e garantia fundamental, visto que o princípio objetiva assegurar a força dirigente e vinculante dos direitos e garantias de feição fundamental, isto é, ele tem como escopo tornar os referidos direitos prerrogativas diretamente aplicáveis pelo Poder Legislativo, Executivo e Judiciário.

O direito à alimentação ao ter sido constitucionalizado como direito fundamental social expressamente tipificado no art. 6 da Constituição brasileira de 1988 tem, por força do art. 5으, § 1으, aplicação imediata.

Logo, constitui um direito social de imediata prestação sob a forma de preceito juridicamente obrigatório e vinculante, independentemente de qualquer interposição legislativa infraconstitucional.

Acerca do conteúdo expresso no art. 2ำ, $§ 1^{\circ}$ do PIDESC ao estabelecer que cada Estado-Parte compromete-se a adotar medidas até o máximo de recursos disponíveis que visem a assegurar, progressivamente, por todos os meios apropriados, o pleno exercício dos direitos (econômicos, sociais e culturais) reconhecidos no presente pacto, ${ }^{49}$ não se refere à

48 Nesse sentido: ANDRADE, 2004, p. 392. Em sentido diverso, tem-se a posição de Jorge Miranda (2000, p. 384) ao lecionar que os direitos econômicos, sociais e culturais são, em parte, suscetíveis de beneficiar de regras homólogas das regras formuladas para os direitos, liberdades e garantias, por modelação de princípios gerais do ordenamento jurídico. E assevera que "[...] ao tempo da entrada em vigor das normas constitucionais já se verificarem os pressupostos - econômicos, financeiros, institucionais - da efetivação, tais normas podem ser entendidas como tendo aplicação imediata (mesmo se o reconhecimento desses pressupostos e, por vezes, a determinação ou determinabilidade das normas exigem uma intervenção do legislador".

49 O art. 2으, § 10 do Pacto Internacional dos Direitos Econômicos, Sociais e Culturais dispõe, in verbis: "Cada Estado Membro no presente Pacto compromete-se a adotar medidas, tanto por esforço próprio como pela assistência e cooperação internacionais, principalmente nos planos econômico e técnico, até o máximo de seus recursos disponíveis, que visem a assegurar, progressivamente, por todos os meios apropriados, o pleno exercício dos direitos reconhecidos no presente Pacto, incluindo, em particular, a adoção de medidas 
indefinição de metas e prazos e, sim, à sua impulsividade, visto que motiva o desenvolvimento social e econômico a ser alcançado. ${ }^{50}$ Além disso, em consonância com o Comentário Geral de n 3, de 14 de dezembro de 1990 (em sua quinta sessão) ao versar sobre a natureza das obrigações dos Estados-partes afirmou que o Pacto Internacional de Direitos Econômicos, Sociais e Culturais gera para os Estados-partes tanto obrigações de comportamento como obrigações de resultado, isto é, não se trata de que os Estados devam se conduzir de certa maneira, senão também que logrem certos objetivos, que proponham metas e as realizem.

A expressão "progressiva realização" tem o sentido de assegurar a plena realização dos direitos econômicos, sociais e culturais. Por outro lado, a expressão deve ser compreendida à luz do objetivo global, a verdadeira razão de ser, do PIDESC, que é estabelecer obrigações claras para os Estados-partes quanto à plena realização dos direitos em questão. Assim, impõe-se uma obrigação de agir tão rápida e efetivamente quanto possível em direção àquela meta. Além disso, qualquer medida que implique deliberado retrocesso exige-se a mais cuidadosa apreciação e necessita-se ser inteiramente justificada com referência à totalidade dos direitos previstos no Pacto, nomeadamente o direito à alimentação, e no contexto do uso integral do máximo de recursos disponíveis.

$\mathrm{O}$ argumento de desenvolvimento progressivo não pode servir de artifício para a postergação da concretização e efetivação do direito fundamental à alimentação ante a possibilidade de omissão na realização de políticas públicas para este direito.

\section{As políticas públicas brasileira e portuguesa de realização do direito à}

\section{alimentação}

Nesta seção procura-se averiguar se as políticas públicas ${ }^{51}$ brasileira e portuguesa estão a contribuir para a realização do direito à alimentação. No caso da Comunidade dos

legislativas". Reitera-se que o referido Pacto foi adotado pela Resolução no 2.200-A (XXI) da Assembleia Geral das Nações Unidas, em 16 de dezembro de 1966.

General Comment no 3,

December 1990. Disponível em: <http://www2.ohchr.org/english/bodies/cescr/comments.htm>. Acesso em: 18 jan. 2012.

51 Conforme magistério de Maria Paula Bucci (1997, p. 91), a expressão políticas públicas pode designar, de forma geral, a "[...] a coordenação dos meios à disposição do Estado, harmonizando as atividades estatais e privadas para a realização de objetivos socialmente relevantes e politicamente determinados". 
Países de Língua Portuguesa (CPLP) ${ }^{52}$ o que se verifica é que todos os países têm dado claros sinais de empenho político nesta matéria. Embora em estágios diferenciados, todos esses países estão neste momento envolvidos em processos de formulação e/ou implementação de políticas nacionais de Segurança Alimentar e Nutricional (SAN). A análise se deteve nos instrumentos específicos adotados pelos governos brasileiro e português no campo da SAN.

O Brasil constitui atualmente uma das referências mundiais em termos de política nacional de combate à fome, tendo assumido um considerável protagonismo no plano internacional fruto do empenho político demonstrado pelo Governo Lula. O impacto e visibilidade conferido a alguns de seus programas - designadamente no âmbito do Fome Zero -, e os avanços conseguidos com importantes políticas de cunho social colocam o Brasil numa posição de destaque.

O Programa Fome Zero é uma estratégia impulsionada pelo governo federal para assegurar o direito fundamental à alimentação adequada às pessoas com dificuldades de acesso aos alimentos. Tal estratégia se insere na promoção da segurança alimentar e nutricional ao buscar a inclusão social e a conquista da cidadania da população mais vulnerável à fome.

O primeiro ponto positivo do Fome Zero foi priorizar o tema da fome na agenda política brasileira, com repercussões no cenário mundial, além de reforçar a participação e a mobilização da sociedade.

O segundo ponto positivo do Fome Zero foi possibilitar a vinculação entre a Política de Segurança Alimentar e Nutricional e a necessidade de repensar a ação do Estado. Quanto

52 A CPLP foi formada em 17 de julho de 1996 e é integrada pela República Federativa do Brasil, República Portuguesa, República de Angola, República Democrática de São Tomé e Príncipe, República de Moçambique, República de Cabo Verde, República da Guiné-Bissau e República Democrática de Timor Leste.

A CPLP é um fórum político multilateral com estatuto jurídico próprio e um mandato político para fortalecer as relações de amizade e cooperação entre os seus membros tendo, entre outros, os seguintes objetivos principais: 1) Cooperação e coordenação política e diplomática entre os Estados membros; 2) Cooperação em todas as áreas, incluindo educação, saúde, ciência e tecnologia, defesa, agricultura, administração pública, comunicações, justiça, segurança pública, cultura, desporto etc. Tendo em conta a relevância política da comunidade CPLP, a Guiné Equatorial, as Ilhas Maurícias e o Senegal pediram Estatuto de Observador Associado a fim de juntar-se à CPLP no futuro. Outros países da África, da Europa, mas também na Ásia (Filipinas, Indonésia, Macau, Malaca e Goa) têm mostrado interesse para participar na CPLP. A CPLP tem sede em Lisboa (Portugal). As orientações da CPLP e as suas políticas são estabelecidas na Conferência de Chefes de Estado e Governo que se realiza bianualmente. O plano estratégico da organização é aprovado pelo Conselho de Ministros dos Negócios Estrangeiros que se reúne anualmente. Os diferentes setores (Agricultura, Saúde, Educação, Planejamento etc.) reúnem pelo menos uma vez por ano no âmbito ministerial. Mais informações sobre a CPLP pode ser obtida no seguinte portal: <www.cplp.org>. 
mais garantida a integração das áreas envolvidas nesse tema, mais estimuladas as parcerias e melhor promovidos os canais de participação popular e controle social, maior é a possibilidade de consolidação efetiva dessa política. A realização da 2a Conferência Nacional de Segurança Alimentar e Nutricional, em 2004, consolidou o reconhecimento pelo Estado da necessidade de implementação de uma política pública de segurança alimentar e nutricional fortemente apoiada na participação da sociedade brasileira.

O Fome Zero é coordenado pelo Ministério do Desenvolvimento Social e Combate à Fome (MDS) e consiste em mais de trinta programas complementares divididos em quatro eixos articuladores: Eixo 1 - Acesso aos alimentos ${ }^{53}$ (principais programas: Bolsa Família ${ }^{54}$ um programa de transferência de renda ${ }^{55}$; Restaurantes Populares; Bancos de Alimentos; Cisternas; Alimentação Escolar; Agricultura Urbana e Hortas Comunitárias; Distribuição de Vitamina A; Educação Alimentar etc.); Eixo 2 - Fortalecimento da Agricultura Familiar (principais programas: Programa Nacional de Fortalecimento da Agricultura FamiliarPRONAF; Programa de Aquisição de Alimentos da Agricultura Familiar; Seguro de Agricultura Familiar etc.); Eixo 3 - Geração de Renda (principais programas: Qualificação social e profissional; Organização produtiva de comunidades; Microcrédito; Desenvolvimento de Cooperativas etc.); Eixo 4 - Articulação, Mobilização e Controle Social (principais programas:

53 Este eixo contém programas e ações de transferência de renda, alimentação e nutrição e acesso à informação e educação.

54 O Bolsa Família [Lei no 10.836/2004, 9 de janeiro de 2004] é considerado o carro-chefe do Fome Zero, pois é um programa de transferência de renda destinado às famílias em situação de pobreza, com renda familiar per capita de até $\mathrm{R} \$ 140,00$ mensais, que associa a transferência do benefício financeiro com o acesso aos direitos sociais básicos: saúde, alimentação, educação e assistência social. Assim, o Bolsa Família é um programa de transferência direta de renda, porém com condicionalidades ao beneficiar famílias em situação de pobreza e de extrema pobreza. Logo, o Programa integra o Fome Zero que tem como objetivo assegurar o direito fundamental à alimentação adequada, promovendo a segurança alimentar e nutricional e contribuindo para a conquista da cidadania pela população mais vulnerável à fome. Segundo informação haurida no portal do Ministério do Desenvolvimento Social e Combate à Fome (MDS), o Programa Bolsa Família possui três eixos principais: transferência de renda, condicionalidades e programas complementares. A transferência de renda promove o alívio imediato da pobreza. As condicionalidades reforçam o acesso a direitos sociais básicos nas áreas de educação, saúde e assistência social. Já os programas complementares objetivam o desenvolvimento das famílias, de modo que os beneficiários consigam superar a situação de vulnerabilidade. Outros elementos referentes ao Programa Bolsa Família podem ser consultados no seguinte site: <www.mds.gov.br/bolsafamilia>.

55 As políticas de transferência direta de renda consistem no repasse financeiro do Estado aos beneficiários, tendo em vista a satisfação de necessidades básicas. Essas transferências podem ser condicionadas ou incondicionadas. Na 1a categoria vincula-se o repasse financeiro a alguma contraobrigação, seja no campo da saúde, educação etc. Os repasses incondicionados não exigem qualquer requisito para o recebimento do benefício. Outros aspectos pontuais quanto às políticas públicas de transferência direta de renda e críticas a esses tipos de programas, nomeadamente o Programa Bolsa Família, são elucidados por Eduardo Rocha (2011, p. 82-105). 
Mutirões e doações; Parcerias com empresas e outras entidades; Casa das famílias; Capacitação de agentes públicos e locais; Conselhos Sociais etc.).

A análise da SAN hoje no Brasil tem como princípios basilares o Direito fundamental à alimentação e a soberania alimentar. Para além desses dois princípios que the servem de base, a política brasileira nesta matéria assume ainda outras características que a diferenciam, designadamente: a) a colocação da SAN como estratégia de desenvolvimento; b) a intersetorialidade das suas ações e políticas; e c) o elevado nível de mobilização e participação social inerente.

Em Portugal, a garantia da SAN perpassa diferentes setores de governo, designadamente por meio de programas para a agricultura, medidas de proteção social e planos específicos da saúde. A questão alimentar assume destaque no âmbito do setor agrícola com forte vinculação à política protecionista da União Europeia. A garantia de reservas alimentares coordenadas entre o Ministério da Agricultura e os serviços de proteção civil merecem também referência neste contexto. No caso deste país, especial destaque deve ser dado à dimensão da segurança dos alimentos (food safety) onde estão em curso medidas importantes, inclusive por órgãos próprios como, por exemplo, a Autoridade de Segurança Alimentar e Econômica (ASAE) (PINTO, 2011, p. 28). ${ }^{56}$

Vale ainda destacar a política de cooperação portuguesa que contempla o tema da SAN e da luta contra a fome no quadro dos Objetivos de Desenvolvimento do Milênio $(\mathrm{ODM})^{57}$ e da cooperação Norte-Sul. O Instituto Português de Apoio ao Desenvolvimento

56 A ASAE é a autoridade administrativa portuguesa especializada no âmbito da segurança alimentar e da fiscalização econômica. É responsável pela avaliação e comunicação dos riscos na cadeia alimentar, bem como pela disciplina do exercício das atividades econômicas nos setores alimentar e não alimentar, mediante a fiscalização e prevenção do cumprimento da legislação reguladora de cada uma delas. A ASAE rege-se pelos princípios da independência científica, da precaução, da credibilidade e transparência e da confidencialidade.

57 Em setembro de 2000, representantes de 191 Estados-Membros da Organização das Nações Unidas (ONU), incluindo 147 Chefes de Estado, assinaram a Declaração do Milênio considerado o mais importante compromisso internacional em favor do desenvolvimento e da eliminação da pobreza e da fome no mundo. A Declaração refletiu objetivos previamente acordados sobre direitos humanos e direito ao desenvolvimento, notadamente os presentes no Pacto Internacional de Direitos Econômicos Sociais e Culturais, de 1966, na Declaração das Nações Unidas sobre o Direito ao Desenvolvimento (Resolução 41/123 de 1986, da Assembleia Geral da ONU, e nos documentos finais das conferências mundiais sobre temas sociais da década de 1990). A Declaração do Milênio deu origem a uma série de objetivos de desenvolvimento concretos e mensuráveis conhecidos como Objetivos de Desenvolvimento do Milênio (ODM). Os oito ODM definidos pelas Nações Unidas, a serem alcançados até 2015, referem-se ao seguinte: (1) erradicar a extrema pobreza e a fome; (2) atingir o ensino básico universal; (3) promover a igualdade entre os sexos e a autonomia das mulheres; (4) reduzir a mortalidade infantil; (5) melhorar a saúde da 
(IPAD) é a estrutura do governo responsável pela implementação da política de cooperação. Os países africanos lusófonos e Timor Leste são os principais destinatários da estratégia de cooperação portuguesa. A segurança alimentar e o desenvolvimento rural figuram como prioridades nessa estratégia (PINTO, 2011, p. 29).

\section{Conclusão}

O epílogo de um trabalho representa, muitas vezes, a alegria de uma missão cumprida. Não deixa de ser o caso desta pesquisa que, em fase conclusiva, representa um passo inicial de invocar a atenção para a urgente tarefa de efetivar o direito fundamental à alimentação ao empreender as políticas públicas nacionais indispensáveis, visto que tal direito se encontra, indiscutivelmente, consagrado e reconhecido no domínio do Direito Internacional e em várias Constituições estatais.

Os direitos fundamentais foram consagrados e reconhecidos internacionalmente ao longo da história da humanidade, sobretudo com a aprovação pela Assembleia Geral das Nações Unidas, em 10 de dezembro de 1948, da Declaração Universal dos Direitos Humanos que constitui o marco inaugural no desenvolvimento da ideia contemporânea de direitos humanos ao assentar a posição de universalidade, indivisibilidade, interdependência e interrelacionariedade, sob uma perspectiva sistêmica, de que todos os direitos fundamentais são igualmente importantes, ou seja, não há sobreposição entre eles, sejam direitos civis e políticos, sejam direitos sociais. Assim, em seu artigo 25 , ela discorreu sobre o direito à alimentação de forma mais ampla e o tratou como integrante do direito a um padrão de vida que pudesse assegurar saúde e bem-estar.

A necessidade de explicitar de forma mais acurada os direitos previstos na Declaração Universal dos Direitos Humanos ao tornar seus dispositivos juridicamente vinculantes e obrigatórios, nomeadamente os referentes aos direitos sociais, foi aprovado o Pacto Internacional dos Direitos Econômicos, Sociais e Culturais (PIDESC) que, no seu artigo 11, apresenta norma específica sobre o direito à alimentação. Tal direito é indivisivelmente vinculado à dignidade da pessoa humana, sendo indissociável da justiça social, requerendo

mulher; (6) combater o HIV/AIDS, a malária e outras doenças; (7) garantir a sustentabilidade ambiental; (8) estabelecer uma parceria mundial para o desenvolvimento. 
aos atores estatais a adoção de políticas econômicas, ambientais e sociais, tanto no âmbito nacional como internacional, orientadas para a erradicação da pobreza e da fome.

A segurança alimentar é a garantia de todos os seres humanos em ter acesso físico e econômico aos alimentos básicos e indispensáveis para o alcance de uma vida ativa e saudável. Por isso, a fim de conquistar tal objetivo, requer-se a participação de uma multiplicidade de atores institucionais como o Estado, movimentos sociais, Organizações Não Governamentais e a sociedade civil como um todo na obtenção de políticas públicas que intervenham diretamente na efetivação e concretização do direito fundamental à alimentação ao suplantar, por conseguinte, a fome.

Ademais, é preciso pensar que a alimentação é um direito e não um favor do Estado para os que não têm o que comer. Se é direito, deve estar ao alcance de todos, devendo desfrutar e reivindicar o cumprimento de toda a normatividade deste direito fundamental. Por essa razão, o Estado incumbe-se no dever de assegurar o acesso à alimentação não só em quantidade suficiente, mas também em qualidade a fim de completar a sustentabilidade da vida.

Nesse sentido, destacou-se a relevância do transcurso temporal aliada aos esforços despendidos para o alargamento da abrangência do direito a uma alimentação adequada ao superar o seu aspecto quantitativo e alçar o caráter qualitativo da alimentação e sua correspondência com a segurança alimentar e nutricional.

Sustentou-se que o direito fundamental à alimentação constitui um direito autônomo por ser dotado de fundamentalidade formal oriunda da alteração firmada no artigo 6으 da Constituição brasileira de 1988, bem como seu reconhecimento explícito no art. 25 da Declaração Universal dos Direitos Humanos e no art. 11 do Pacto Internacional dos Direitos Econômicos, Sociais e Culturais (PIDESC), bem como pela sua fundamentalidade material que decorre pela sua congruência com o superprincípio da dignidade da pessoa humana.

\section{Referências}

ALEXANDRINO, José Melo. Direitos fundamentais: introdução geral. 2. ed. rev. atual. Cascais: Princípia, 2011. 
. A indivisibilidade dos direitos do homem à luz da dogmática constitucional. In: ALEXANDRINO, José Melo. O discurso dos direitos. Coimbra: Coimbra Editora, 2011.

ALEXY, Robert. Teoría de los derechos fundamentales. Tradução de Carlos Bernal Pulido. 2. ed. Madri: Centro de Estudios Politicos e Constitucionales, 2007.

ANDRADE, José Carlos Vieira de. Os direitos fundamentais na Constituição portuguesa de 1976. 3. ed. Coimbra: Edições Almedina, 2004.

BANDEIRA DE MELLO, Celso Antônio. Eficácia das normas constitucionais sobre justiça social. Revista de Direito Público, São Paulo, n. 57-58, p. 233-256, 1981.

BITENCOURT NETO, Eurico. O direito ao mínimo para uma existência digna. Porto Alegre: Livraria do Advogado, 2010.

BONAVIDES, Paulo. Curso de direito constitucional. 14. ed. São Paulo: Malheiros Editores, 2004.

BRASIL. Ministério do Desenvolvimento Social e Combate à Fome. Disponível em: $<$ http://www.mds.gov.br>.

Página oficial da Presidência da República do Brasil. Disponível em:

$<$ http://www2.planalto.gov.br>.

. Supremo Tribunal Federal. Disponível em: <http://www.stf.jus.br>.

BUCCl, Maria Paula Dallari. Políticas públicas e direito administrativo. Revista de Informação Legislativa, Brasília, n. 133, p. 89-98, jan./mar.1997.

CANOTILHO, José Joaquim Gomes. Direito constitucional e teoria da Constituição. 7. ed. Coimbra: Livraria Almedina, 2003.

CARVALHO, Osvaldo Ferreira de. Segurança jurídica e a eficácia dos direitos sociais fundamentais. Curitiba: Juruá, 2011.

COMITÊ dos Direitos Econômicos, Sociais e Culturais (conferir os comentários gerais de números 3 e 12 que foram expendidos, respectivamente, sobre a natureza das obrigações dos Estados-partes do PIDESC e sobre o direito a uma alimentação adequada). Disponível em: <http://www.gddc.pt/direitos-humanos/onu-proteccao-dh/PAGINA2-1-dir-econ.html>.

COMPARATO, Fábio Konder. A afirmação histórica dos direitos humanos. 6. ed. rev. e atual. São Paulo: Saraiva, 2008. 
COMUNIDADE dos Países de Língua Portuguesa. Disponível em: <http://www.cplp.org>.

DANTAS, Miguel Calmon. Constitucionalismo dirigente e pós-modernidade. São Paulo: Saraiva, 2009.

DECLARAÇÃO Universal dos Direitos Humanos (adotada pela Nações Unidas em 10 de dezembro de 1948). Disponível em:

<http://www.ohchr.org/EN/UDHR/Pages/UDHRIndex.aspx>.

DIMOULIS, Dimitri; MARTINS, Leonardo. Teoria geral dos direitos fundamentais. São Paulo: RT, 2007.

FAO. Declaração de Roma sobre Segurança Alimentar Mundial e Plano de Ação da Cúpula Mundial da Alimentação. Roma, 1996. Disponível em:

<http://www.fao.org/DOCREP/003/W3613P/W3613P00.HTM\#Note1>. Acesso em: 8 jan. 2012.

FREITAS, Juarez. A interpretação sistemática do direito. 5. ed. São Paulo: Malheiros, 2010.

GOMES, Luiz Flávio; MAZZUOLI, Valerio de Oliveira. Direito supraconstitucional: do absolutismo ao Estado Constitucional e humanista de direito. São Paulo: RT, 2010. (Coleção de Direito e Ciências Afins, v. 5).

GuATEMALA. Constituição Política da República da Guatemala. Disponível em:

<http://www.cc.gob.gt/DocumentosCC/ConstitucionGuatemala.pdf>.

LAFER, Celso. A reconstrução dos direitos humanos: um diálogo com o pensamento de Hannah Arendt. São Paulo: Companhia das Letras, 1988.

LEDUR, José Felipe. A realização do direito ao trabalho. Porto Alegre: Sergio Antonio Fabris Editor, 1998.

. Direitos fundamentais sociais: efetivação no âmbito da democracia participativa.

Porto Alegre: Livraria do Advogado, 2009.

LUÑO, Antonio Enrique Pérez. Los derechos fundamentales. 8. ed. Madrid: Editorial Tecnos, 2004.

. Derechos humanos, Estado de Derecho y Constitución. 9. ed. Madrid: Tecnos, 2005.

MANIGLIA, Elisabete. As interfaces do direito agrário e dos direitos humanos e a segurança alimentar. São Paulo: Cultura Acadêmica, 2009. 
MAZZUOLI, Valerio de Oliveira. Curso de Direito Internacional Público. 2. ed. rev. atual. e ampl. São Paulo: RT, 2007.

. Coletânea de Direito Internacional. 8. ed. rev. ampl. e atual. São Paulo: RT, 2010. (Coleção RT MiniCódigos).

Os direitos fundamentais e seus múltiplos significados na ordem constitucional. Revista Diálogo Jurídico, Salvador, CAJ - Centro de Atualização Jurídica, n. 10, p. 1-12, jan. 2002. Disponível em: <http://www.direitopublico.com.br>. Acesso em: 12 maio 2008.

MÉXICO. Constituição. Disponível em:

<http://www.diputados.gob.mx/LeyesBiblio/pdf/1.pdf>.

MIRANDA, Jorge. Manual de Direito Constitucional: direitos fundamentais. 3. ed. rev. e atual. Coimbra: Coimbra Editora, 2000. v. 4.

. Manual de Direito Constitucional: Constituição. 6. ed. rev. e atual. Coimbra: Coimbra Editora, 2007. v. 2.

Manual de Direito Constitucional: direitos fundamentais. 4. ed. rev. e atual.

Coimbra: Coimbra Editora, 2008. v. 4.

MIRANDA, Jorge; MEDEIROS, Rui. Constituição portuguesa anotada. 2. ed. Coimbra: Coimbra Editora, 2010. v. 1.

NEUNER, Jörg. Os direitos humanos sociais. Revista Direito Público, Porto Alegre, n. 26, p. 18-41, mar./abr. 2009.

NOVAIS, Jorge Reis. Os princípios constitucionais estruturantes da república portuguesa. Coimbra: Coimbra Editora, 2004.

. Direitos fundamentais: trunfos contra a maioria. Coimbra: Coimbra Editora, 2006.

. Contributo para uma teoria do Estado de Direito. Coimbra: Almedina, 2006.

ORGANIZAÇÃO das nações unidas. Disponível em: <http://www.un.org/en/>.

OTERO, Paulo. Instituições políticas e constitucionais. Coimbra: Edições Almedina, 2009. v. 1.

PACTO Internacional sobre Direitos Econômicos, Sociais e Culturais (PIDESC) - Aprovado pela Assembleia Geral da ONU por meio da Resolução 2.200-A (XXI) em 16 de dezembro de 1966: <http://portal.mj.gov.br/sedh/ct/legis_intern/pacto_dir_economicos.htm>. 
PINTO, João N. Direito à Alimentação e Segurança Alimentar e Nutricional nos Países da CPLP. Diagnóstico de Base (Relatório sobre a institucionalidade da segurança alimentar e nutricional e direito à alimentação nos países da Comunidade dos Países de Língua Portuguesa), Coimbra, p. 1-57, jun. 2011. Disponível em: <http://www.actuar-acd.org>. Acesso em: 08 dez. 2011.

PIOVESAN, Flávia. Não à desconstitucionalização dos direitos sociais. São Paulo: Consultor Jurídico, 2000. Disponível em: <http://www.conjur.com.br/2000-jun-

02/conquistas_trabalhistas_preservadas>. Acesso em: 30 jul. 2009.

Direitos sociais, econômicos e culturais e direitos civis e políticos. Revista Internacional de Direitos Humanos, São Paulo, n. 1, p. 20-47, jan./jun. 2004.

Direitos humanos e o Direito Constitucional Internacional. 7. ed. rev. ampl. e atual. São Paulo: Saraiva, 2006.

. Proteção dos direitos econômicos, sociais e culturais e do direito à alimentação adequada: mecanismos nacionais e internacionais. In: PIOVESAN, Flávia; CONTI, Irio Luiz (Coord.). Direito humano à alimentação adequada. Rio de Janeiro: Lumen Juris, 2007. p. 1748.

. Concepção contemporânea de direitos humanos: desafios e perspectivas. In: ROCHA, João Carlos de Carvalho; HENRIQUES FILHO, Tarcísio Humberto Parreiras; CAZETTA, Ubiratan (Coord.). Direitos humanos: desafios humanitários contemporâneos. Belo Horizonte: Del Rey, 2008.

Temas de direitos humanos. 3. ed. São Paulo: Saraiva, 2009.

PORTUGAL. Tribunal Constitucional de Portugal. Disponível em:

$<$ http://www.tribunalconstitucional.pt/tc/home.html>.

PROGRAMA das Nações Unidas para o Desenvolvimento. Disponível em:

<http://www.pnud.org.br>.

QUEIROZ, Cristina. O princípio da não reversibilidade dos direitos fundamentais sociais: princípios dogmáticos e prática jurisprudencial. Coimbra: Coimbra Editora, 2006.

. Direitos fundamentais sociais: funções, âmbito, conteúdo, questões interpretativas e problemas de justiciabilidade. Coimbra: Coimbra Editora, 2006.

QUÊNIA. Constituição. Disponível em:

<http://www.kenyalaw.org/klr/fileadmin/pdfdownloads/Constitution_of_Kenya_2010.pdf> 
ROCHA, Cármen Lúcia Antunes. O príncipio da dignidade da pessoa humana e a exclusão social. Interesse Público, Belo Horizonte, v. 1, n. 4, out./dez. 1999. Disponível em:

$<$ http://www.bidforum.com.br/bid/PDlexibepdf.aspx?vw=S\&pdiCntd=51781>. Acesso em: 8 dez. 2012.

SARLET, Ingo Wolfgang. Os direitos fundamentais sociais na Constituição de 1988. Revista Diálogo Jurídico, Salvador, v. 1, n. 1, p. 1-45, abr. 2001. Disponível em:

<http://www.direitopublico.com.br>. Acesso em: 12 dez. 2011.

. A eficácia dos direitos fundamentais. 8. ed. rev. e atual. Porto Alegre: Livraria do Advogado, 2007.

. Dignidade da pessoa humana e direitos fundamentais na Constituição Federal de 1988. 5. ed. rev. e atual. Porto Alegre: Livraria do Advogado, 2007.

. Os direitos sociais como direitos fundamentais: seu conteúdo, eficácia e efetividade no atual marco jurídico-constitucional brasileiro. In: LEITE, George Salomão; SARLET, Ingo Wolfgang (Coord.). Direitos fundamentais e Estado constitucional: estudos em homenagem a J. J. Gomes Canotilho. São Paulo: RT; Coimbra: Coimbra Editora, 2009. cap. 10.

SARMENTO, Daniel. Direitos fundamentais e relações privadas. 2. ed. Rio de Janeiro: Editora Lumen Juris, 2008.

TAVARES, André Ramos. Curso de Direito Constitucional. 3. ed. rev. e atual. São Paulo: Saraiva, 2006.

VALENTE, Flávio Luiz Schieck. Direito humano à alimentação: desafios e conquistas. São Paulo: Cortez, 2002.

. Fome, desnutrição e cidadania: inclusão social e direitos humanos . Saúde e Sociedade, São Paulo, v. 12, n. 1, p. 51-60, jun. 2003.

WEIS, Carlos. Direitos humanos contemporâneos. São Paulo: Malheiros, 1999.

WORLD FOOD PROGRAMME (Programa Alimentar Mundial - PAM). Disponível em: $<$ http://www.wfp.org/>. 